\title{
CHANGES IN ZIRCON CHEMISTRY DURING ARCHEAN UHT METAMORPHISM IN THE NAPIER COMPLEX, ANTARCTICA
}

\author{
MONIKA A. KUSIAK $* * * * * *, \dagger$, MARTIN J. WHITEHOUSE*, SIMON A. WILDE**, \\ DANIEL J. DUNKLEY**, MARTINA MENNEKEN ${ }^{\S}$, ALEXANDER A. NEMCHIN**, $^{*}$, \\ and CHRIS CLARK**
}

\begin{abstract}
Zircons from two paragneisses (from Mount Sones and Dallwitz Nunatak) and one orthogneiss (from Gage Ridge) in the Tula Mountains, Napier Complex (East Antarctica) were analyzed for U-Pb age, oxygen isotopes, REEs and by scanning ion imaging. A large number of zircons from all samples are reversely discordant. Mount Sones zircons show an age range from 3.0 Ga to $2.5 \mathrm{Ga}$ and underwent high-grade metamorphism at both $\sim 2.8 \mathrm{Ga}$ and $2.5 \mathrm{Ga}$. Zircons from Dallwitz Nunatak record detrital ages between $3.5 \mathrm{Ga}$ and $2.5 \mathrm{Ga}$. Zircons from Gage Ridge record multiple age groups, with concordant data between $3.6 \mathrm{Ga}$ and $3.3 \mathrm{Ga}$ and reversely discordant data that form a discrete $\sim 3.8 \mathrm{Ga}$ population. All of the grains show evidence of $\mathrm{Pb}$ mobility during metamorphism. Ion imaging of zircons reveals $\mathrm{Y}$ and $\mathrm{U}$ zonation, characteristic of magmatic zircon, together with a micro-scale patchy distribution of ${ }^{206} \mathrm{~Pb}$ and ${ }^{207} \mathrm{~Pb}$ that does not correspond to either growth zonation or crystal imperfections. Some of these patches yield ${ }^{207} \mathrm{~Pb} /{ }^{206} \mathrm{~Pb}$ ages $>4$ $\mathrm{Ga}$, whereas others yield ages younger than the magmatic crystallization age. Reversely discordant data are the result of ancient $\mathrm{Pb}$ mobilization, which is independent of the degree of metamictisation, oxygen isotope and REE content of the zircons. This mobilization can result in spurious ages and was most likely caused by polymetamorphism under anhydrous conditions; that is two high-grade events; one poorly defined at $\sim 2.8 \mathrm{Ga}$ and the other ultra-high temperature (UHT) metamorphism at $2.5 \mathrm{Ga}$.
\end{abstract}

Key words: Antarctica, geochronology, SIMS, ion imaging, zircon

\section{INTRODUCTION}

More than any other mineral, zircon $\left(\mathrm{ZrSiO}_{4}\right)$ has been the target of geochronological studies, due to properties that allow a wealth of geological information to be encoded within its structure. As a chemically and physically robust mineral that incorporates $\mathrm{U}$ and $\mathrm{Th}$, but initially excludes $\mathrm{Pb}$, zircon commonly retains accumulated radiogenic $\mathrm{Pb}$ despite weathering or metamorphism of the host rock, and is therefore the mineral of choice for U-Th-Pb geochronology (for example Davis and others, 2003 and references therein). Moreover, as a result of the extremely low diffusivity of $\mathrm{Pb}$ in zircon (Cherniak and Watson, 2003; Cherniak, 2010), it preserves isotopic systematics even through high-grade metamorphic events. However, although zircon is the most popular geochronometer, its U-Pb isotope systematics can be disturbed by certain geological processes, leading to discordance between the ages calculated from the independent U-Pb systems ${ }^{238} \mathrm{U} /{ }^{206} \mathrm{~Pb}$ and ${ }^{235} \mathrm{U} /{ }^{207} \mathrm{~Pb}$ (Ahrens, 1955). In most cases, discordance is due to an apparent deficiency of radiogenic $\mathrm{Pb}$ relative to $\mathrm{U}$, when compared to the $\mathrm{Pb}$ content predicted by the ratio of daughter products $\left({ }^{207} \mathrm{~Pb} /{ }^{206} \mathrm{~Pb}\right)$. This is termed "normal discordance," in contrast to "reverse discordance" where U-Pb ages are significantly older than ${ }^{207} \mathrm{~Pb} /{ }^{206} \mathrm{~Pb}$ ages. For the

\footnotetext{
* Swedish Museum of Natural History, Box 50007, SE104 05 Stockholm, Sweden

** Department of Applied Geology, Curtin University, PO BOX U1987, Perth, Western Australia 6845, Australia

*** Institute of Geological Sciences, Polish Academy of Science, ul. Twarda 51/55, 00-818 Warsaw, Poland

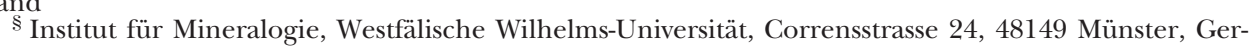
many

${ }^{+}$Corresponding author: monika.kusiak@twarda.pan.pl
} 
correct interpretation of isotopic data it is crucial to understand whether U-Pb age discordance is analytically induced or due to real disturbance of parent-daughter isotope distributions. Because the isotopes ${ }^{206} \mathrm{~Pb}$ and ${ }^{207} \mathrm{~Pb}$ are not significantly fractionated relative to each other (Shimizu and Hart, 1982), either by natural processes or by SIMS analysis, ${ }^{207} \mathrm{~Pb} /{ }^{206} \mathrm{~Pb}$ ages are less susceptible to such disturbances. Thus, especially in studies of Paleoproterozoic and older zircon where $\mathrm{U}-\mathrm{Pb}$ ages are less precise than ${ }^{207} \mathrm{~Pb} /{ }^{206} \mathrm{~Pb}$ ages, the latter are generally regarded as more reliable, with normal discordance attributed to "Pb loss" through a variety of mechanisms. The concept of "Pb gain" or "U loss" to produce reverse discordance, on the other hand, is not widely appreciated; such data tend to be ignored, and few studies are available that have directly addressed this problem (see Williams and others, 1984; White and Ireland, 2012; Kusiak and others, 2013).

As well as a robust recorder of radioisotope evolution, zircon is also regarded as a valuable carrier of other geochemical information, including oxygen and hafnium isotope compositions, and titanium and rare earth element (REE) concentrations. Zircon typically preserves primary oxygen isotope compositions, due to low oxygen diffusivity even under conditions of high-grade metamorphism or intense hydrothermal alteration (Peck and others, 2003; Valley, 2003). Other elements, like REE, that can be incorporated in the crystal structure of zircon, may also be useful for unraveling petrogenetic associations (for example Speer, 1980; Belousova and others, 2002). Characteristic REE concentrations and patterns have been proposed for distinguishing zircon from different geological environments (Hoskin and Schaltegger, 2003; Whitehouse and Platt, 2003).

Pre-3.6 Ga rocks are rare on Earth, with most studies being focused on localities in Canada (for example Bowring and others, 1989) and Greenland (for example Whitehouse and others, 1999) as well as on detrital zircon from Western Australia (for example Cavosie and others, 2005 and references therein). Although rocks as old as $3.93 \mathrm{Ga}$ are present in Antarctica, they have received little attention compared to the more accessible locations, with studies focused on the pervasive high-grade metamorphism and zircon response to it (Black and others, 1986a, 1986b; Harley and Black, 1997; Carson and others, 2002a, 2002b; Kelly and Harley, 2005). A recent study (Kusiak and others, 2013) has shown that $\mathrm{Pb}$ mobilization can cause spurious zircon ages in these rocks. In that study two grains of similar age $(3.4 \mathrm{Ga})$, but different $\mathrm{U}$ contents, were utilized and it was evident that the grains showed an uneven $\mathrm{Pb}$ distribution.

Here, we present results from complex zircon grains from layered ortho- and paragneisses from Mount Sones, Dallwitz Nunatak and Gage Ridge (Napier Complex, Antarctica) with different ${ }^{207} \mathrm{~Pb} /{ }^{206} \mathrm{~Pb}$ ages $(2.8 \mathrm{Ga}, 3.0 \mathrm{Ga}, 3.6 \mathrm{Ga}$ and $3.8 \mathrm{Ga}$, respectively) to determine the effect of metamorphism, including a $\sim 2.5 \mathrm{Ga}$ ultra-high temperature (UHT) event, on the isotopic record. We have utilized ion imaging, together with U-Pb geochronology, oxygen isotope, REE and Raman spectral analyses to provide additional information about the relationships between reversely discordant zircons and their structural and chemical features following UHT metamorphism.

GEOLOGICAL SETTING

The Napier Complex is a granulite-facies terrane that forms the large promontory of Enderby Land, East Antarctica, between longitudes $47^{\circ} \mathrm{E}$ and $56^{\circ} \mathrm{E}$ (fig. 1). Investigations since the 1960 s by Australian, Russian and Japanese scientists have outlined a basic framework for the Archean geological history of the Napier Complex (summarized by Sheraton and others, 1987; Harley and Kelly, 2007; Ishizuka, 2008a, 2008b; and Hokada and others, 2008), which includes at least two high-grade metamorphic events: at $\sim 2.8 \mathrm{Ga}$ and $\sim 2.5 \mathrm{Ga}$ (Kelly and Harley, 2005). The complex comprises granitic, charnockitic and enderbitic gneisses, intercalated with lesser amounts of felsic 


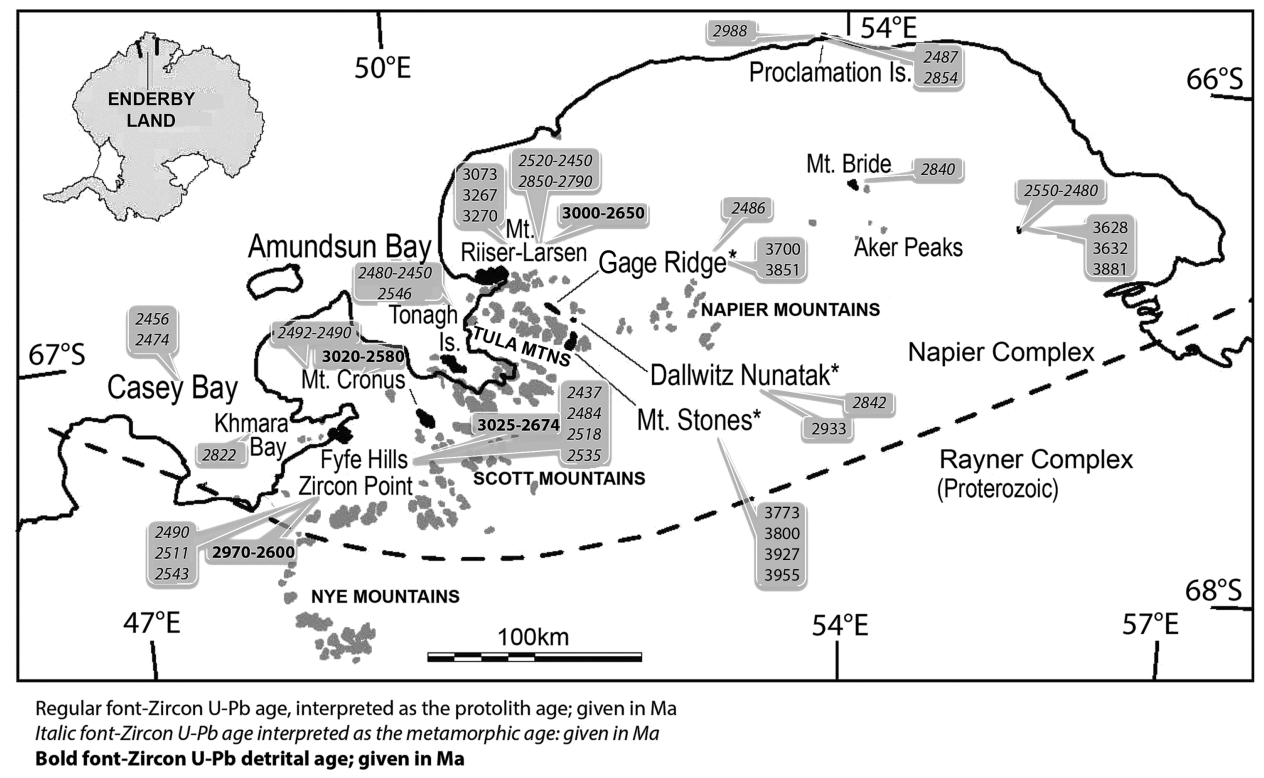

Fig. 1. Outcrop map of the Napier Complex, Enderby Land, East Antarctica (modified after Carson and others, 2002). * = localities of samples used in this study. Data sources from: Black and others, 1983a, 1986b; Williams and others, 1984; Harley and Black, 1997; Carson and others, 2002a, 2002b; Hokada and others, 2003, 2004; Kelly and Harley, 2005; Suzuki and others, 2006; Belyatsky and others, 2011; Horie and others, 2012.

and pelitic paragneisses, and minor proportions of mafic to ultramafic orthogneisses and meta-ironstones (Sheraton and others, 1987; Harley and Black, 1997; Hokada and others, 2004). In the vicinity of Casey Bay, Amundsen Bay and the Tula Mountains (fig. 1), mineral assemblages that include sapphirine + quartz, osumilite, high-Al orthopyroxene, and/or high-Ca mesoperthite, record UHT metamorphic conditions between 1050 and $1120^{\circ} \mathrm{C}$, at pressures that increase from north to south from 7 to $11 \mathrm{kbars}$ (Dallwitz, 1968; Harley, 1987; Hensen and Motoyoshi, 1992; Harley and Motoyoshi, 2000; Hokada and others, 2008). A stage of decompression under UHT conditions has been recognized in some localities (Hollis and Harley, 2002; Hokada and others, 2008; Shimizu and others, 2012); however, the general post-peak metamorphic evolution is that of isobaric cooling (Harley, 1985; Harley and Hensen, 1990; Hensen and Motoyoshi, 1992; Osanai and others, 1999; Shimizu and others, 2012).

Peak metamorphism was associated with the regional development of a predominantly subhorizontal to shallowly-dipping gneissosity and intense mineral lineation, along with macro-scale recumbent isoclinal folding $\left(D_{1}\right.$ of James and Black, 1981; Sandiford and Wilson, 1984; Sheraton and others, 1987; Toyoshima and others, 2008). Tight inclined to recumbent macro-scale folds $\left(\mathrm{D}_{2}\right)$ are recognized in some localities (James and Black, 1981; Sheraton and others, 1987), and regionally developed upright, open folds $\left(\mathrm{D}_{3}\right.$, Sheraton and others, 1987) were developed during widespread retrograde metamorphism, producing a regional dome-and-basin structure (Toyoshima and others, 2008). Hokada and others (2008) and Toyoshima and others (2008) suggested that the complex can be divided by inferred faults and/or shearzones into a number of blocks that have been exhumed to different levels, accounting for pressure differences in peak assemblages from north to south. Amphibolite-facies shear zones are recognized at several localities, in places accompanied by pegmatites 
(Sheraton and others, 1987; Carson and others, 2002b). A variety of mafic dikes of different generations that vary from sheared to undeformed, cut across the gneisses in most localities (Sheraton and others, 1987; Suzuki others, 2008). The regional extent and timing of peak deformation and UHT metamorphism has long been debated; however it should be kept in mind that structural field studies in Enderby Land are of limited extent and that regional correlations are necessarily tentative.

EARLIER GEOCHRONOLOGY

As is the case with the structural history, the timing of crust formation, protolith generation and other earlier geological events is generally obscured by the pervasiveness and intensity of a major tectono-metamorphic event at $c a .2 .5 \mathrm{Ga}$ (see Sheraton and others, 1987; Kelly and Harley, 2005; Hokada and others, 2008). The available datasets are also restricted by the lack of sample availability, especially from inland localities. As a result, the same samples have been re-analyzed and reassessed in several papers, although this has been accompanied by the application of newly-available or refined techniques. Consequently, age estimates from later studies generally supersede those reported in earlier studies - an important point when considering the evidence both for near-Hadean zircon and for the timing of UHT metamorphism.

The oldest ages reported, obtained from U-Pb ion microprobe dating of zircon from felsic orthogneiss and paragneiss samples from Mount Sones and Gage Ridge in the Tula Mountains (fig. 1), are scattered between $c a .4 .1$ and $3.9 \mathrm{Ga}$ (Black and others, 1986b; Harley and Black, 1997; Kelly and Harley, 2005), but for the most part are reversely discordant, and therefore of questionable significance. Early estimates for the age of the protolith of the Mount Sones orthogneiss (3955 $\pm 10 \mathrm{Ma}$, Williams and others, 1984; 3927 $\pm 10 \mathrm{Ma}$, Black and others, 1986b) were not supported by re-analysis that yielded a concordia intercept age of $3800+50 /-100 \mathrm{Ma}$ (Harley and Black, 1997). This revised age for magmatism coincides with other best estimates for orthogneiss from Mount Sones (3773 \pm 13 Ma, Harley and Black, 1997) and nearby Gage Ridge (3851 \pm 62 Ma, Kelly and Harley, 2005; superseding Harley and Black, 1997$3700 \pm 250 \mathrm{Ma}$ ). Eoarchean zircon ages have not been found elsewhere in the Napier Complex, with the exception of a single 3981 \pm 8 Ma grain from enderbitic orthogneiss from Aker Peaks in western Kemp Land (fig. 1), which Belyatsky and others (2011) interpreted as recording the age of the magmatic protolith. They also report grouped concordant zircon ages from multiple samples of charnockitic and enderbitic gneisses of $3632 \pm 12 \mathrm{Ma}$ and $3628 \pm 23 \mathrm{Ma}$, respectively, which they attribute to magmatism during a granulite-facies event; however, no evidence for metamorphism at this time was presented, nor are the relationships between magmatic $3980 \mathrm{Ma}$ and $3630 \mathrm{Ma}$ zircon grains from enderbite explained. Thus the significance of these results remains unclear.

Elsewhere, the entrainment of Eoarchean or Paleoarchean crust in the Napier Complex has been demonstrated only by the presence of scant ages from detrital zircons in paragneisses of the Tula Mountains (for example from Mount Sones and Dallwitz Nunatak; Harley and Black, 1997), and in depleted mantle Nd model ages from a variety of gneisses from Amundsen Bay and the Tula Mountains (Shiraishi and others, 2008 and references therein). Model Nd ages from orthogneisses cluster around $c a .3 .9 \mathrm{Ga}$ at Mount Sones, 3.7 to $3.1 \mathrm{Ga}$ on Tonagh Island, 3.4 Ga at Mount Riiser-Larsen and 3.5 to $3.2 \mathrm{Ga}$ in the Fyfe Hills (fig. 1). These indicate significant crustal growth or reworking during the Paleoarchean; however, actual protolith ages have been established only for the end of the Paleoarchean to the Mesoarchean, with the zircon U-Pb dating of felsic orthogneisses from Mount Riiser-Larsen (3270 $12 \mathrm{Ma}$,

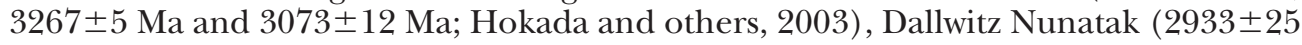
Ma, zircon, Kelly and Harley, 2005) and Proclamation Island (2988 23 Ma, Kelly and Harley, 2005). A Rb-Sr whole rock age of $3100 \pm 75$ Ma may also suggest the presence of 
old granitoid protoliths in the Fyfe Hills (Black and others, 1983a, 1983b), and discrete populations of $c a$. 3.0 Ga detrital zircons in paragneisses from Fyfe Hills and Mount Cronus suggest the presence of rocks of this age in the western Napier Complex (Asami and others, 2002; Horie and others, 2012).

A late Mesoarchean episode of high-grade metamorphism and deformation has been recognized from widespread localities. U-Pb zircon ages that are regarded as dating metamorphism were reported from Khmara Bay (2822 $222 \mathrm{Ma}$, Harley and Black, 1997), Dallwitz Nunatak (2842 \pm 16 Ma, Kelly and Harley, 2005, superseding Harley and Black, 1997), Mount Riiser-Larsen (2850-2790 Ma, Hokada and others, 2003), and Proclamation Island (2854 \pm 14 Ma, Kelly and Harley, 2005). Harley and Black (1997) regarded this episode as involving the highest grade of metamorphism, consistent with ages from supposedly syn-tectonic intrusions. Such magmatic ages have been identified at Dallwitz Nunatak (Harley and Black, 1997), Mount Bride (2840 280 Ma, Rb-Sr, Black and others, 1986b) and Mount Riiser-Larsen ( $c a .2830$ Ma zircon, Suzuki and others, 2006). However, Kelly and Harley (2005) reassessed these ages in light of REE compositions of metamorphic zircon from the Dallwitz Nunatak orthogneiss, which established the absence of garnet (present in the UHT paragenetic assemblage) during ca. 2850 Ma metamorphism, and concluded that such zircon growth occurred during a low-P high-T (but not UHT) event. Exactly which event, 2.8 Ga or subsequent 2.5 Ga metamorphism, relates to regional $\mathrm{D}_{1}$ is unclear; rather it is likely that high strain fabrics cannot be readily correlated between widely-separated localities.

Neoarchean zircon ages for protoliths of felsic orthogneisses at Fyfe Hills (ca. 2741 Ma, Horie and others, 2012) and Tonagh Island (2626 $28 \mathrm{Ma}$, Carson and others, 2002a) provide upper constraints on the timing of UHT metamorphism. These are consistent with zircon data from paragneisses from several localities, which yield detrital ages with remarkably consistent ranges: 2970 to 2600 Ma (Zircon Point; Kelly and Harley, 2005), 3025 to 2674 Ma (Fyfe Hills; Horie and others, 2012), 3020 to 2580 Ma (Mount Cronus; Horie and others, 2012) and 3000 to 2650 Ma (Mount RiiserLarsen; Hokada and others, 2004). The oldest estimates for the major tectonometamorphic episode that reworked $c a$. 2800 Ma gneisses and younger igneous and sedimentary lithologies into a single high-strain gneissic terrane come from metamorphic zircon, and concentrate at $c a .2540 \mathrm{Ma}$ in multiple localities ( $c a .2535$ and 2518

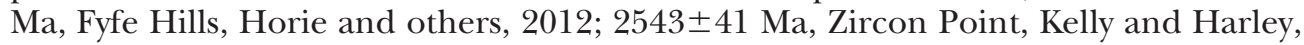
2005; 2546 $13 \mathrm{Ma}$, Tonagh Island, Carson and others, 2002a). In all these localities, this event was followed by subsequent episodes of growth (ca. 2484 and $2437 \mathrm{Ma}$ at Fyfe Hills, Horie and others, 2012; 2511 \pm 17 and 2490 \pm 17 Ma at Zircon Point, Kelly and Harley, 2005; and 2480-2450 Ma at Tonagh Island, Carson and others, 2002a). Ages of zircon growth that do not define precise stages are found elsewhere (2520-2450 Ma at Mount Riiser-Larsen, Hokada and others, 2003, 2004; Suzuki and others, 2006; and 2550-2480 Ma at Aker Peaks, Belyatsky and others, 2011). Samples from other localities record only a single episode at $c a .2490 \mathrm{Ma}$ (2492-2490 Ma at Mount Cronus, Horie and others, 2012; 2485 \pm 14 Ma at Dallwitz Nunatak, Kelly and Harley, 2005; 2486 6 Ma at Gage Ridge, Kelly and Harley, 2005; and 2487 10 Ma at Proclamation Island, Kelly and Harley, 2005). Due to this complexity in zircon age data, there is disagreement as to whether peak ultra-high temperatures were attained during the earlier ( $c a .2540$ Ma) or later (ca. $2490 \mathrm{Ma}$ ) stages of zircon growth. Kelly and Harley (2005) argue for peak metamorphism occurring shortly before or at $c a .2540 \mathrm{Ma}$, with later zircon growth at $c a .2490 \mathrm{Ma}$ occurring during cooling and crystallization of anatectic melt. Horie and others (2012) hypothesize that $c a .2490$ Ma zircon at Mount Cronus could be a product of fluid activity, a suggestion consistent with the post-peak interpretation of Kelly and Harley (2005). In contrast, Grew (1998) suggested that UHT conditions 
are also recorded by syn-deformational pegmatites at Casey Bay (fig. 1) that were dated by Black and others (1983a) at $2474 \pm 3 \mathrm{Ma}$ and $2456 \pm 8 \mathrm{Ma}$. However, as the latter cut gneissic fabrics and are only deformed by late $\left(\mathrm{D}_{3}\right)$ folding and shearing, they are best considered as providing a lower age limit to the episode of high-T metamorphism and high-strain deformation in the Napier Complex. Subsequent to this, there is only local evidence of deformation and metamorphism, largely restricted to discrete mylonitic shear zones (dated at $c a$. 2550-2470 Ma by Crowe and others, 2002). Late pegmatite intrusions provide age estimates for later minor events, possibly associated with metamorphism (for example $c a .2200$ Ma zircon in pegmatite, Grew and others, 2001; ca. 1930-1800 Ma for fluid-altered zircon adjacent to pegmatite, Carson and others, 2002b; and 498 \pm 2 Ma for monazite in pegmatite, Carson and others, 2002b).

SAMPLES

The three samples utilized in this study were collected from the Tula Mountains (fig. 1) by Pat James during the 1978 Australian National Antarctic Research Expedition.

\section{Mount Sones (Sample 14178-1; n3852), Paragneiss}

Sample 14178-1 is a paragneiss from Mount Sones. It is dominated by quartz and mesoperthite and contains low modal proportions of idiomorphic garnet, cordierite, K-feldspar and orthopyroxene, with accessory zircon, rutile and monazite. Quartz contains numerous exsolved rutile needles oriented within its crystal lattice. Distributed throughout the rock are fine-grained intergrowths of cordierite + K-feldspar + quartz; some of these intergrowths contain dendritic orthopyroxene. This assemblage can be interpreted to represent the breakdown of former osumilite, indicating this rock attained ultra-high temperature conditions. Small euhedral zircon crystals are observed in the cordierite + K-feldspar + quartz intergrowths. However, the location of zircon is not restricted to this microstructure and it can be found distributed throughout the rock.

\section{Dallwitz Nunatak-945 Peak (Sample 11178-1; n3847), Sapphirine-Bearing Paragneiss}

This rock is quartz-rich containing volumetrically minor sapphirine, orthopyroxene and mesoperthite, with accessory zircon and rutile. Isolated intergrowths of K-feldspar + cordierite + quartz are distributed throughout the rock and are interpreted to have formed by the breakdown of peak osumilite. Sapphirine is observed in textural equilibrium with orthopyroxene and quartz, suggesting the rock experienced temperatures in excess of $900^{\circ} \mathrm{C}$. Locally, sapphirine is separated from quartz by a thin corona of cordierite. The coarse-grained quartz contains abundant exsolved rutile needles whose orientations appear to be crystallographically controlled. Some of the geochronological results from this sample were published in the data repository by Kusiak and others (2013): in this paper they are presented in table 1.

\section{Gage Ridge (Sample 16178-2; n3850), Orthogneiss}

This sample is a strongly layered felsic, pyroxene-bearing orthogneiss and was collected from the same sample site on the same expedition as sample 78285013 investigated by Harley and Black (1997) and Kelly and Harley (2005). It is composed of granoblastic mesoperthite and quartz with scattered trails of orthopyroxene defining a coarse gneissosity. Some of the geochronological results from this sample were published in the data repository of Kusiak and others (2013): in this paper they are presented in table 2 .

\section{METHODOLOGY}

Zircon grains were separated by standard crushing and heavy-liquid techniques, mounted in epoxy resin along with the Geostandards 91500 zircon (Wiedenbeck and 


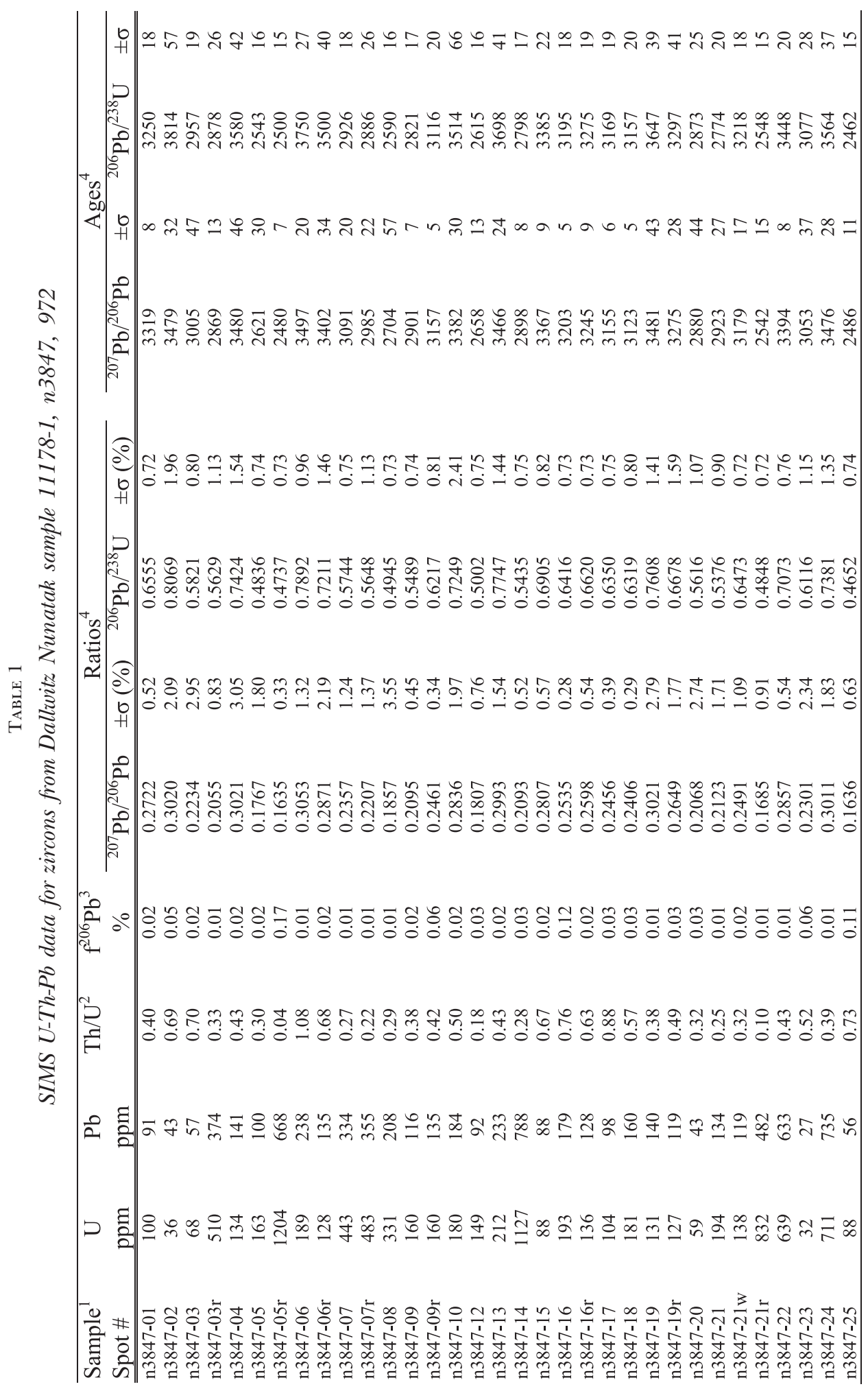




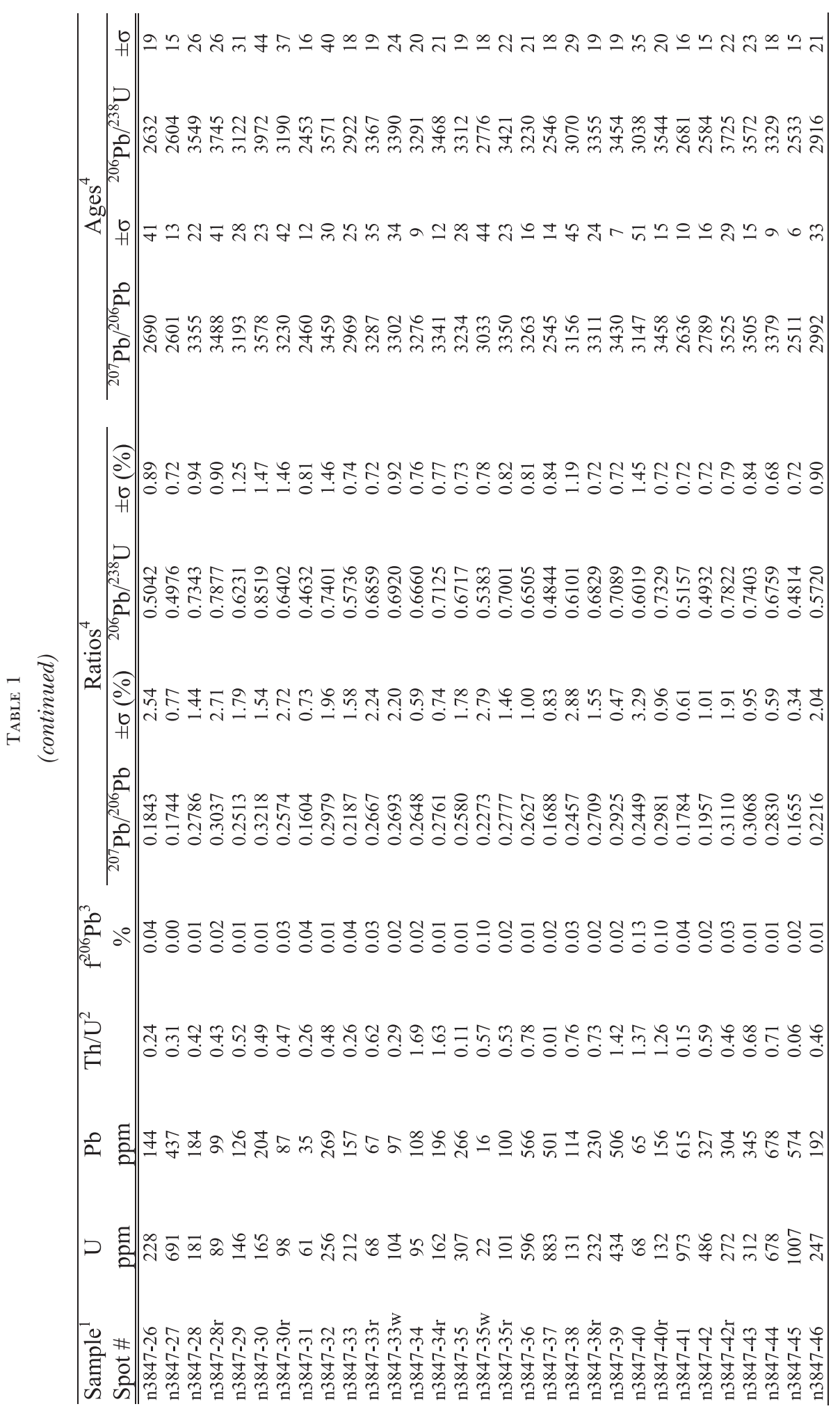




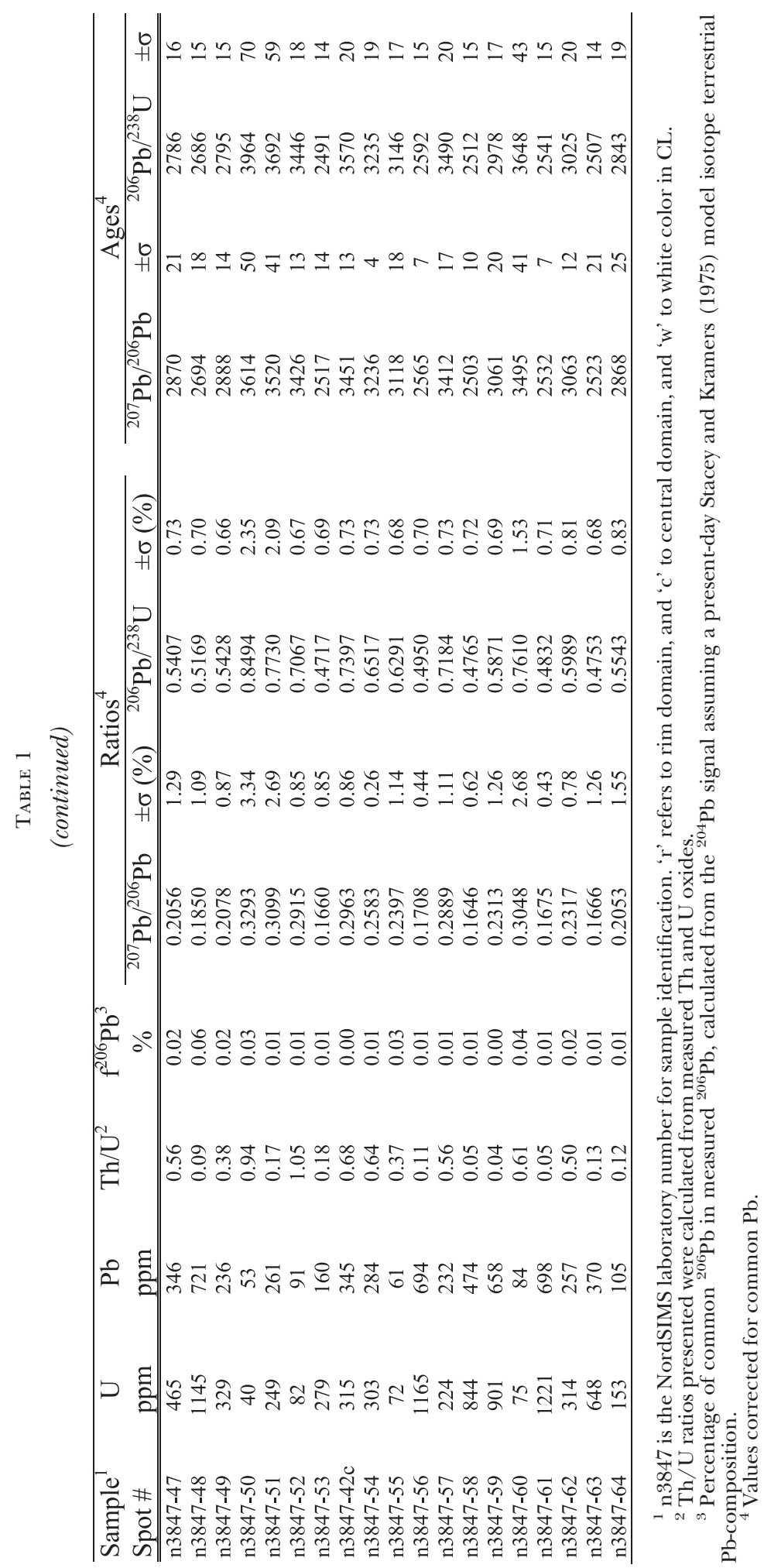




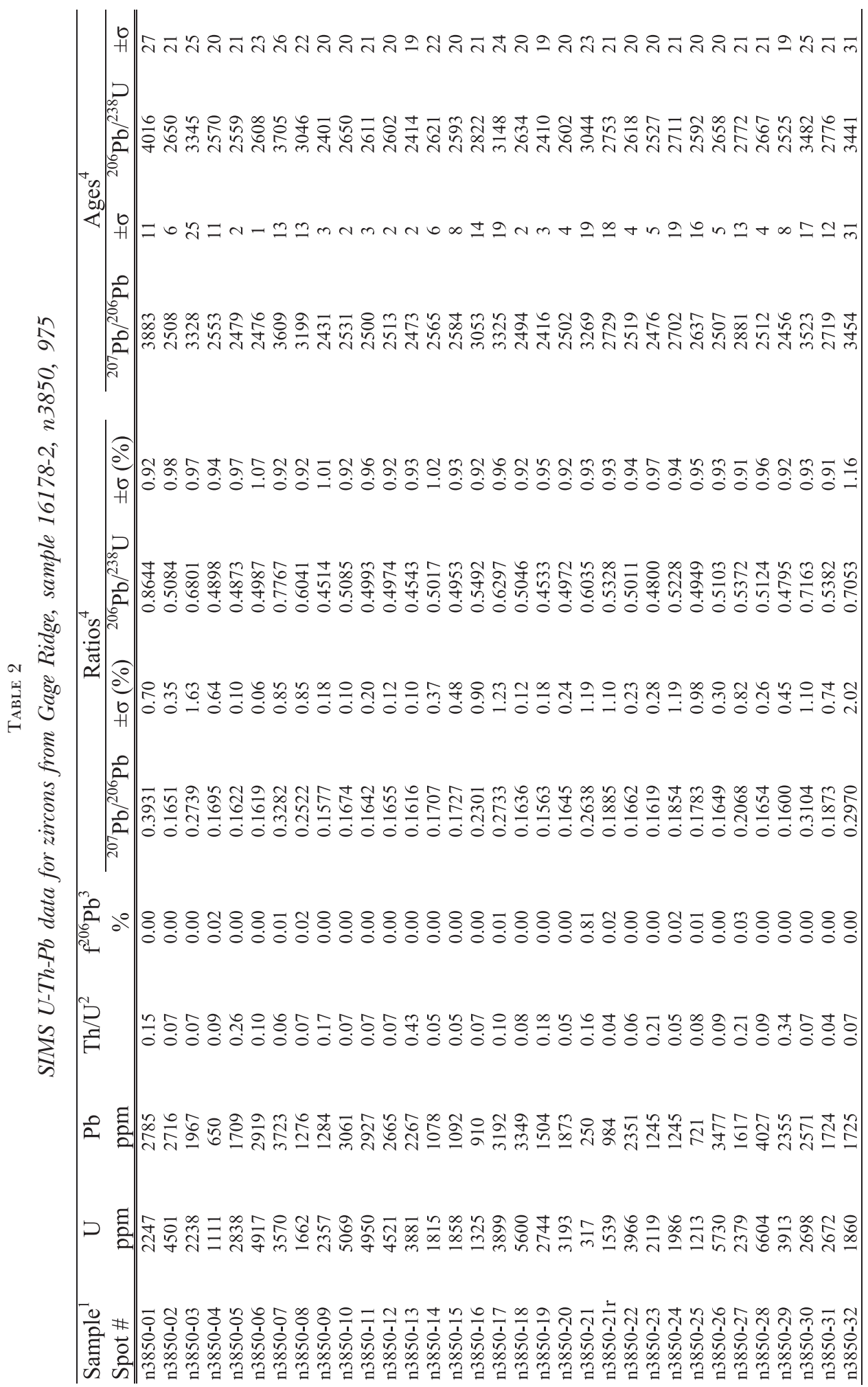




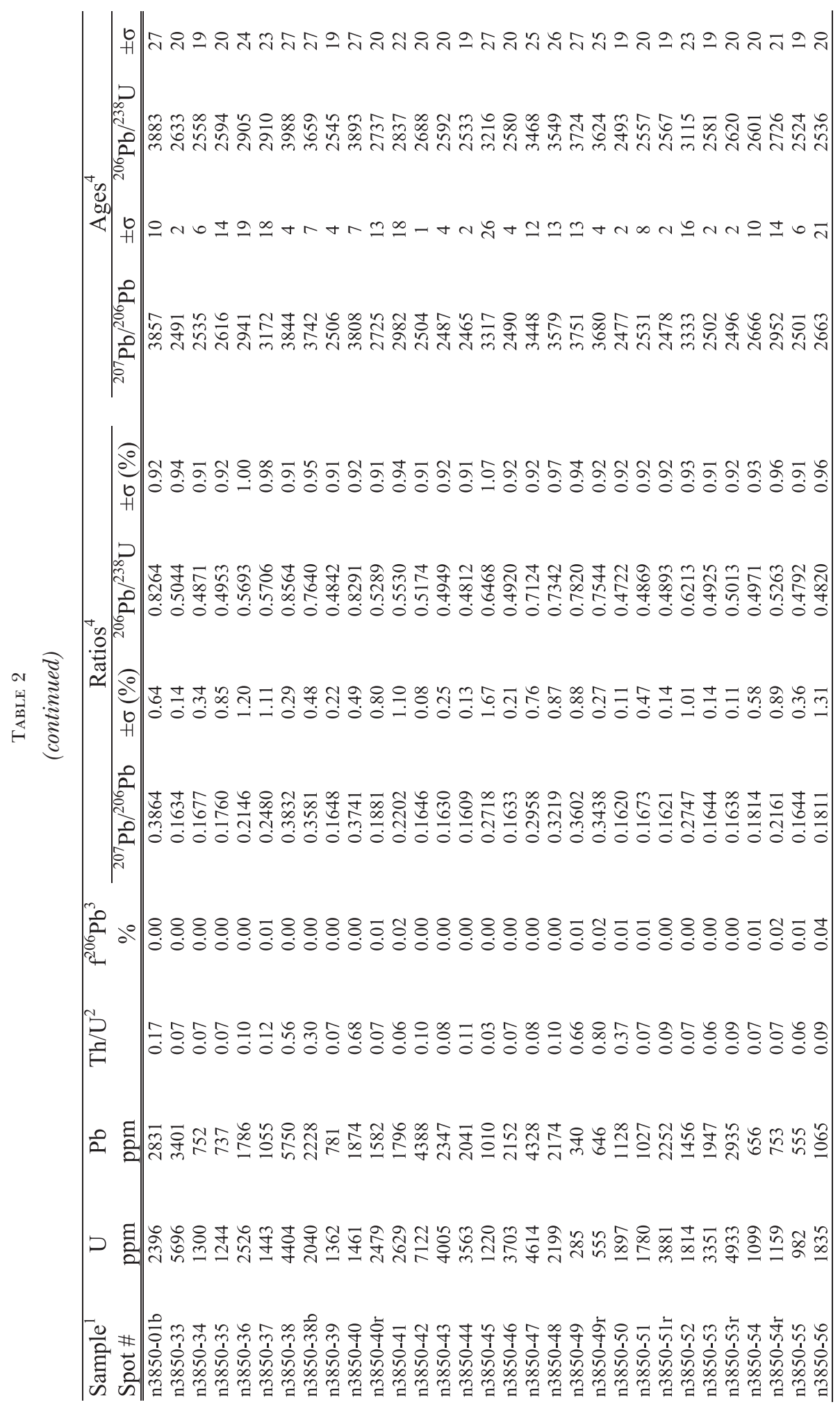




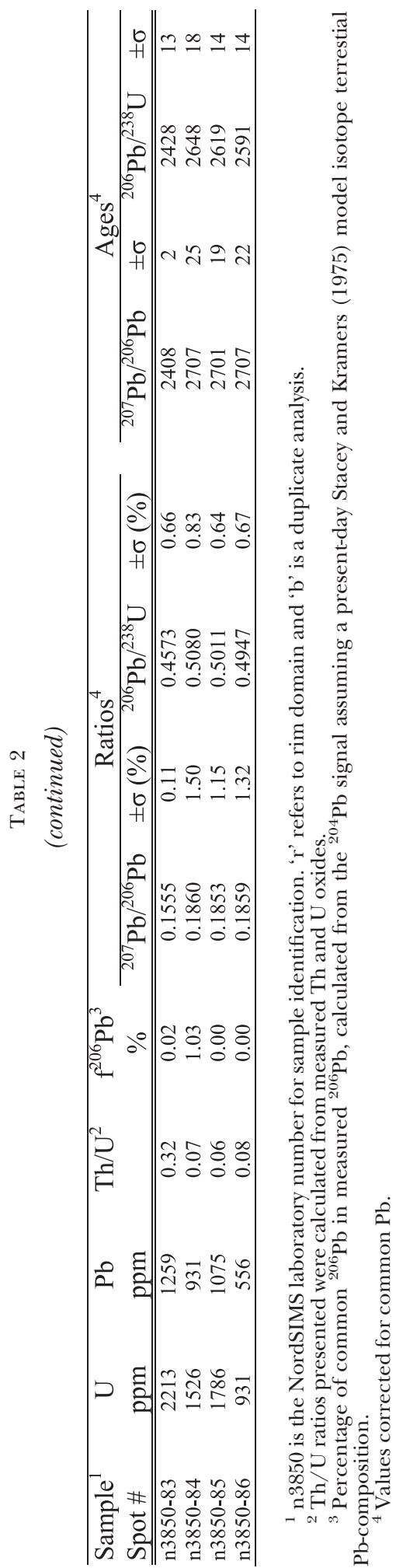


others, 1995) and polished to reveal their interiors. Back-scattered electron (BSE) and cathodoluminescence (CL) images were obtained to characterize the internal structure of the grains. The CAMECA IMS 1280 ion-microprobe at the Swedish Museum of Natural History, Stockholm (NordSIMS facility), was used for zircon geochronology (U-Pb dating in single-collector mode and $\mathrm{Pb}-\mathrm{Pb}$ multi-collector mode) and for oxygen and REE analyses; additionally, selected grains were mapped by Scanning Ion Imaging (SII). Spot analysis for U-Pb closely follows the method described by Whitehouse and Kamber (2005) using a $c a .15 \mu \mathrm{m}, 6 \mathrm{nA} \mathrm{O}{ }_{2}^{-}$primary beam, and peak-hopping mono-collection with an ion counting electron multiplier (EM) at a mass resolution of ca. $5400(\mathrm{M} / \Delta \mathrm{M})$. Common $\mathrm{Pb}$ was corrected using the ${ }^{204} \mathrm{~Pb}$ counts assuming $\mathrm{a}$ present-day terrestrial Pb-isotope composition model (Stacey and Kramers, 1975) following the rationale of Zeck and Whitehouse (1999) that this is largely surface contamination introduced during sample preparation, and not common $\mathrm{Pb}$ residing in zircon and/or micro-inclusions. Very low amounts of common $\mathrm{Pb}$ were detected during the spot analyses with $f^{206} \mathrm{~Pb}<0.1$ percent, in many cases below the detection limit for ${ }^{204} \mathrm{~Pb}$ based on the electron multiplier background. Where common $\mathrm{Pb}$ corrections were deemed necessary on the basis of measurable ${ }^{204} \mathrm{~Pb}$, these were small and therefore insensitive to the precise composition of the common $\mathrm{Pb}$. Subsequent $\mathrm{Pb}$-isotope spot analyses used four multi-collector EMs to detect the Pb isotopes ${ }^{206} \mathrm{~Pb},{ }^{207} \mathrm{~Pb}$ and ${ }^{208} \mathrm{~Pb}$, as well as ${ }^{204} \mathrm{~Pb}$. Data reduction was performed using the NordSIMSdeveloped suite of software of M.J. Whitehouse.

For ion imaging, an aperture illuminated ( $\left.c a .2-4 \mu \mathrm{m}, c a .200 \mathrm{pA}_{2}{ }^{-}\right)$primary beam was rastered over an area of $70 \times 70 \mu \mathrm{m}$. Peak hopping mono-collection at a mass resolution of 5400 was used to image ${ }^{89} \mathrm{Y},{ }^{180} \mathrm{Hf},{ }^{206} \mathrm{~Pb}$, and ${ }^{238} \mathrm{U}$. Further, $\mathrm{Pb}-$ isotope imaging used four multi-collector EMs to detect the uranogenic $\mathrm{Pb}$ isotopes ${ }^{206} \mathrm{~Pb}$ and ${ }^{207} \mathrm{~Pb}$, as well as ${ }^{204} \mathrm{~Pb}$ and a matrix peak $\left({ }^{180} \mathrm{Hf}^{16} \mathrm{O}\right.$ at mass 196). The instrument was set to a mass resolution of $4860(\mathrm{M} / \Delta \mathrm{M})$, sufficient to separate $\mathrm{Pb}$ from molecular interferences. Detector backgrounds were assessed separately using long integrations with the secondary ion beam blanked and were typically $\sim 0.01 \mathrm{cps}$. Relative detector yields were measured using a peak-hopping routine, putting the same species (HfO) sequentially into each detector, and were within \pm 5 percent. Secondary ion signals were sufficiently low that dead-time corrections were insignificant. Image analysis was performed using the Cameca WinImage software. Following correction for detector gains, ${ }^{207} \mathrm{~Pb} /{ }^{206} \mathrm{~Pb}$ ratios were corrected for common $\mathrm{Pb}$ based on measured ${ }^{204} \mathrm{~Pb} /{ }^{206} \mathrm{~Pb}$ ratios.

Oxygen isotopic analyses were performed using similar methods to those described by Whitehouse and Nemchin (2009), utilizing a critically focused $\mathrm{Cs}^{+}$primary beam with a spot size of $c a .10 \mu \mathrm{m}$, a low energy, normal incidence electron flooding device for charge compensation and simultaneous detection of ${ }^{16} \mathrm{O}$ and ${ }^{18} \mathrm{O}$ in two Faraday detectors. Measured isotopic ratios were normalized to a $\delta^{18} \mathrm{O}$ value of +9.86 permil (relative to SMOW) for the reference zircon 91500. Minor linear drift corrections $(<1 \mathrm{ppm} / \mathrm{run})$ were applied to the data sets, where applicable, based on minimizing the external error on the standards.

Rare earth element concentrations in selected zircon grains were made using the same SIMS instrument and on the same analytical sites used for geochronology and oxygen measurements: the detailed methodology is described by Whitehouse (2004). The calibration standard was NIST SRM 610, and the concentration values follow Pearce and others (1997). The values for C1 normalization were taken from Anders and Grevesse (1989).

Raman measurements of two zircon grains (Dallwitz Nunatak, grain identifier n3847-44 and Gage Ridge, grain identifier: n3850-47) were conducted at the Mineralogical Institute of the University of Münster, Germany, using a Horiba Xplora 
dispersive Raman spectrometer. Raman scattering was excited by the $638 \mathrm{~nm}$ line of a He-Ne laser and the scattered Raman light was analyzed with a charged-coupled device (CCD) detector after being dispersed by a grating of 1800 grooves per $\mathrm{mm}$ and passed through a $100 \mu \mathrm{m}$ entrance slit. The resulting spectral resolution was about $3.5 \mathrm{~cm}^{-1}$. A confocal aperture of $500 \mu \mathrm{m}$ was used to collect the spectra. Maps were obtained with a $100 \times$ objective, resulting in a lateral resolution of about $1 \mu \mathrm{m}$ and steps of $1 \mu \mathrm{m}$. Measured FWHM (Full Widths at Half Maximum; the width of a spectral emission at the $50 \%$ amplitude points) were calculated using the equation given by Irmer (1985).

RESULTS

\section{Sample 14178-1, n3852-970; Mount Sones, Paragneiss}

All zircon grains have a very low response in CL, obscuring any internal structure. Eighteen grains were analyzed for U-Pb age, with 26 spots selected in the central and outer parts of the grains to test for age variations (table 3). No core-rim differences were distinguished in any zircon grains. All sites record high $\mathrm{U}$ and Th contents, up to 5268 ppm and 383 ppm, respectively. Outer parts of the analyzed zircons are characterized by lower Th content $(<200 \mathrm{pm})$, resulting in slightly lower $\mathrm{Th} / \mathrm{U}$ ratios, although all are low and vary between 0.12 and 0.04 . The proportion of common $\mathrm{Pb}$ is generally insignificant $\left({ }^{206} \mathrm{~Pb} /{ }^{204} \mathrm{~Pb}>15000\right)$. Most of the analyses are a few percent reversely discordant, distributed along a broadly linear array on the concordia diagram with apparent ${ }^{207} \mathrm{~Pb} /{ }^{206} \mathrm{~Pb}$ ages ranging from $3058 \pm 12$ to $2495 \pm 12 \mathrm{Ma}$ (fig. 2A). Analyses of the outer parts of the grains are concentrated in the reversely discordant part of the array, with ${ }^{207} \mathrm{~Pb} /{ }^{206} \mathrm{~Pb}$ ages between $3055 \pm 4$ and $2975 \pm 7 \mathrm{Ma}$. As most of the data are reversely discordant, a regression line was fitted to the data anchored to a lower intercept value of $2500 \pm 50 \mathrm{Ma}$. This value was chosen as an approximation of the age of the UHT event in the Napier Complex, and incorporates best estimates for the age of metamorphism from various sources (Grew and others, 2001; Carson and others, 2002a; Kelly and Harley, 2005). The upper intercept of the regression line is $2810 \pm 60$ Ma, MSWD 3.4. Ten grains were also analyzed using the multi-collector mode (table 4) and the weighted mean ${ }^{207} \mathrm{~Pb} /{ }^{206} \mathrm{~Pb}$ age was $3032 \pm 14 \mathrm{Ma}$. There is a broad positive correlation between the amount of discordance and the $\mathrm{U}$ concentration, but no correlation between age and $\mathrm{Th} / \mathrm{U}$ ratio. As is evident from figure $3 \mathrm{~B}$, all analyses of the outer parts of zircons (black diamonds) record the oldest ages ( $c a .3000 \mathrm{Ma}$ ) with a $\mathrm{Th} / \mathrm{U}$ ratio $<1$.

Eight oxygen isotope analyses were made on 7 grains. The $\delta^{18} \mathrm{O}$ ranges between 7.2 and 8.9 permil (table 5 ), with an average of $8.1 \pm 0.2$ permil $(2 \sigma)$. There is no correlation between $\delta^{18} \mathrm{O}$ and ${ }^{207} \mathrm{~Pb} /{ }^{206} \mathrm{~Pb}$ age, or between $\mathrm{U}, \mathrm{Th} / \mathrm{U}$ and $\delta^{18} \mathrm{O}$ values (fig. 4). The same grains were selected for rare earth element analyses (table 6). REE patterns measured in the grain centers (gray diamonds on fig. 5A) are uniform, with typical positive Ce and negative Eu anomalies and steep MREE. Four outliers with LREE enrichment might be analyses incorporating additional material other than zircon (for example monazite micro-inclusions).

\section{Sample 11178-1, n3847-972; Dallwitz Nunatak, Sapphirine-Bearing Paragneiss}

A total of $116 \mathrm{U}-\mathrm{Pb}$ spot analyses were obtained on 98 zircon grains with apparent ${ }^{207} \mathrm{~Pb} /{ }^{206} \mathrm{~Pb}$ ages ranging from $3.6 \mathrm{Ga}$ to $2.4 \mathrm{Ga}$, and define a discordia with an upper intercept age of $3271 \pm 32 \mathrm{Ma}$ and a lower intercept age of $2520 \pm 57 \mathrm{Ma}$. Data anchored to a lower intercept of $2500 \pm 50$ Ma yield an upper intercept age of $3300 \pm 35 \mathrm{Ma}$, MSWD 6.5 (fig. 2B). In CL images, three different types of zircons can be distinguished: 1) those with oscillatory zoning, 2) those with high CL intensity; and 3) those with little or no CL response. Most grains have low U concentrations ( $c a .200 \mathrm{ppm})$, however, there are a few grains with higher $\mathrm{U}(>1000 \mathrm{ppm})$ and Th contents and 


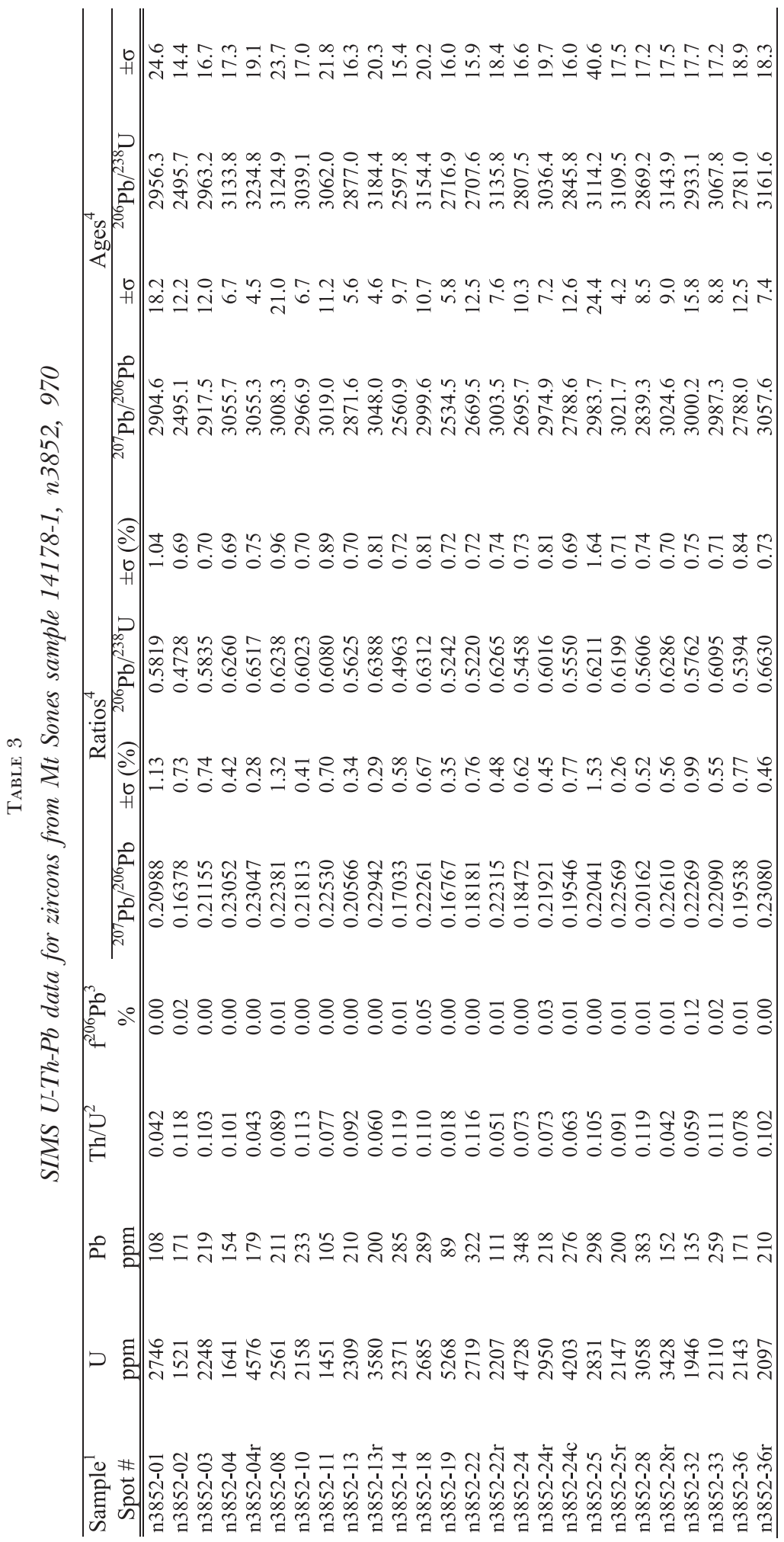



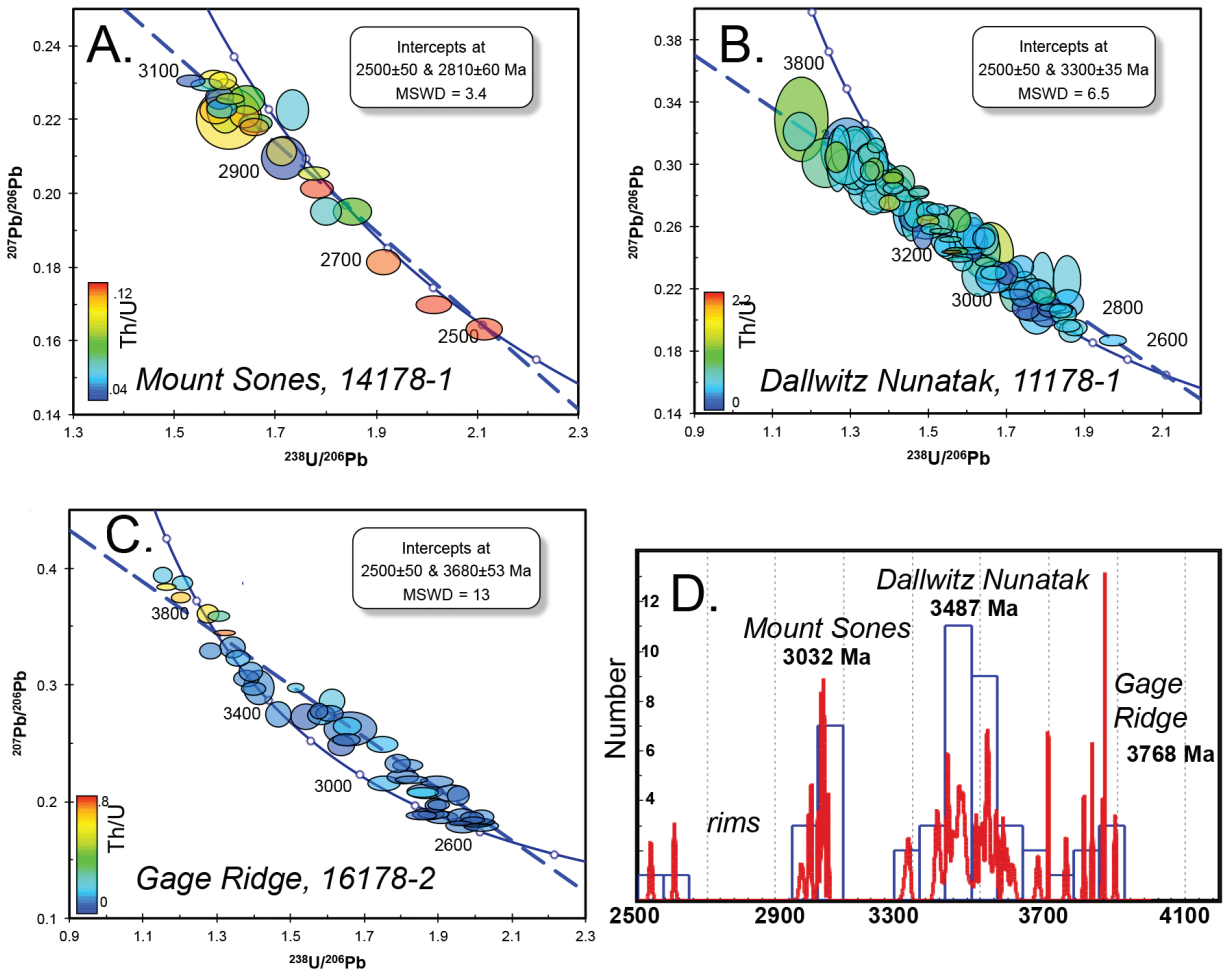

Fig. 2. Tera-Wasserburg concordia diagrams of zircon U-Pb ages: (A) Mount Sones; (B) Dallwitz Nunatak; (C) Gage Ridge; (D) multi-collector data for zircon grains analyzed in all samples. Error ellipses are $2 \sigma$.

$\mathrm{Th} / \mathrm{U}$ ratios. Unlike the Mount Sones sample, there is no correlation between $\mathrm{U}$ content and degree of discordance; however, analyses with U contents above $500 \mathrm{ppm}$ are less scattered (less discordant) than those with lower uranium. There is a positive correlation between ${ }^{207} \mathrm{~Pb} /{ }^{206} \mathrm{~Pb}$ age and $\mathrm{Th} / \mathrm{U}$ (fig. 3D), regardless of whether the analyses were obtained from the central or outer parts of the grains.

Zircon grains with bright CL response (table 1; grains 2, 20, 23, 31, 50, 55, 60, 77), are characterized by low $\mathrm{U}$ and Th contents (31-75 ppm and 15-46 ppm, respectively), with $\mathrm{Th} / \mathrm{U}$ ratios of 0.25 to 1.08 . Despite this narrow compositional range, the data cover the entire ${ }^{207} \mathrm{~Pb} /{ }^{206} \mathrm{~Pb}$ age range between 3614 and $2460 \mathrm{Ma}$.

Grains with no, or very weak, CL response (table 1; grains 22, 24, 44, 45, 48, 56, 58, $61,74,94,97)$, have $\mathrm{U}$ contents much higher than grains with a strong CL response, with two distinguishable ranges of 565 to $844 \mathrm{ppm}$ and 1007 to $1267 \mathrm{ppm}$ (with one outlier of $390 \mathrm{ppm}$ ). Thorium content varies from 40-782 $\mathrm{ppm}$ and $\mathrm{Th} / \mathrm{U}$ ratio varies between 2.16 and 0.01 with one outlier of 4.14. Similar to the grains with bright CL response, the ${ }^{207} \mathrm{~Pb} /{ }^{206} \mathrm{~Pb}$ age ranges from 3476 to $2503 \mathrm{Ma}$. Reversely discordant zircons were selected for multi-collector analysis (table 4 ) and yielded a weighted mean ${ }^{207} \mathrm{~Pb} /{ }^{206} \mathrm{~Pb}$ age of $3487 \pm 40 \mathrm{Ma}(\mathrm{n}=20$, fig. $2 \mathrm{D})$.

Fourteen analyses of oxygen isotopes were performed on 9 grains. The $\delta^{18} \mathrm{O}$ values are slightly lower than for zircons from Mount Sones, varying from 6.8 to 8.0 permil with an average of $7.4 \pm 0.1$ permil (table 5 ). There is no correlation between $\delta^{18} \mathrm{O}$ and ${ }^{207} \mathrm{~Pb} /{ }^{206} \mathrm{~Pb}$ age, $\mathrm{U}$ content or $\mathrm{Th} / \mathrm{U}$ ratio (fig. 4). The same grains were analyzed for rare earth elements (table 6) and REE patterns are mostly uniform, with 
TABLE 4

SIMS U-Th-Pb multicollector data for zircons from Mt Sones, Dallwitz Nunatak, and Gage Ridge samples

\begin{tabular}{|c|c|c|c|c|}
\hline \multirow{2}{*}{$\begin{array}{l}\text { Sample }^{1} \\
\text { Spot \# }\end{array}$} & \multicolumn{4}{|c|}{ Ratios $^{2}$} \\
\hline & ${ }^{207} \mathrm{~Pb} /{ }^{206} \mathrm{~Pb}$ & $\pm \sigma(\%)$ & ${ }^{206} \mathrm{~Pb} /{ }^{238} \mathrm{U}$ & $\pm \sigma(\%)$ \\
\hline "n3852-m-36r & 0.2313561 & 0.1192567 & 0.0262952 & 0.0825912 \\
\hline n3852-m-32 & 0.2245134 & 0.1108598 & 0.0116133 & 0.267264 \\
\hline n3852-m-28r & 0.229739 & 0.1099585 & 0.0107678 & 0.0921174 \\
\hline n3852-m-25r & 0.2289857 & 0.0928307 & 0.0240257 & 0.0837732 \\
\hline n3852-m-22r & 0.2296792 & 0.1892469 & 0.0124296 & 0.1227784 \\
\hline n3852-m-11 & 0.2279546 & 0.1445131 & 0.0192031 & 0.1095067 \\
\hline n3852-m-13r & 0.2243925 & 0.1491327 & 0.0149955 & 0.0816212 \\
\hline n3852-m-18 & 0.2222744 & 0.3493903 & 0.0272778 & 0.4552469 \\
\hline n3852-m-08 & 0.2305062 & 0.205372 & 0.0277232 & 0.1537009 \\
\hline n3852-m-04 & 0.2313838 & 0.0981651 & 0.0234296 & 0.1120796 \\
\hline n3847-m-03r & 0.1768701 & 0.1615047 & 0.0442491 & 0.4981454 \\
\hline n3847-m-04 & 0.269219 & 0.4107908 & 0.1059626 & 0.1580643 \\
\hline n $3847-m-05 r$ & 0.1744668 & 0.2140767 & 0.0163971 & 0.4741069 \\
\hline n3847-m-06 & 0.3131398 & 0.2178816 & 0.2676085 & 0.1933194 \\
\hline n3847-m-10 & 0.2846819 & 0.3608831 & 0.131327 & 0.1258595 \\
\hline n3847-m-13 & 0.2984344 & 0.3296232 & 0.1182866 & 0.1677879 \\
\hline n3847-m-19 & 0.291646 & 0.2580608 & 0.1760341 & 0.2643688 \\
\hline n3847-m-24 & 0.3109806 & 0.1786611 & 0.0983972 & 0.0708111 \\
\hline n3847-m-28 & 0.293935 & 0.2173953 & 0.110575 & 0.128786 \\
\hline n3847-m-28r & 0.2867514 & 0.4973949 & 0.1104537 & 0.1934109 \\
\hline n3847-m-74 & 0.3144278 & 0.2606758 & 0.1796068 & 0.0831358 \\
\hline n3847-m-30 & 0.3139916 & 0.2623545 & 0.1314032 & 0.1319067 \\
\hline n3847-m-32 & 0.2858611 & 0.3155998 & 0.1204626 & 0.1107615 \\
\hline n3847-m-43 & 0.2972048 & 0.2529294 & 0.1714338 & 0.2036235 \\
\hline n $3847-m-50$ & 0.3459067 & 0.3079018 & 0.2601389 & 0.1836932 \\
\hline n3847-m-51 & 0.3038073 & 0.8129092 & 0.0497971 & 0.2378957 \\
\hline n3847-m-52 & 0.3257617 & 0.2565804 & 0.240033 & 0.211459 \\
\hline n3847-m-60 & 0.3295953 & 0.3740823 & 0.1566832 & 0.1760327 \\
\hline n3847-m-57 & 0.2911146 & 0.3861081 & 0.1583663 & 0.5005204 \\
\hline n3847-m-42r & 0.3182079 & 0.4025717 & 0.1099743 & 0.3682879 \\
\hline n3850-m-01 & 0.4020672 & 0.1598849 & 0.0403778 & 0.0571501 \\
\hline n3850-m-07 & 0.310757 & 0.1853284 & 0.0152881 & 0.10394 \\
\hline n3850-m-01b & 0.3938052 & 0.1337901 & 0.0431206 & 0.0642614 \\
\hline n3850-m-40 & 0.3862312 & 0.0866048 & 0.1650768 & 0.0665222 \\
\hline n3850-m-38 & 0.3974645 & 0.0406543 & 0.1492093 & 0.0544825 \\
\hline n3850-m-38b & 0.3824071 & 0.1293492 & 0.0682281 & 0.0878314 \\
\hline n3850-m-49 & 0.3695689 & 0.2163332 & 0.1534778 & 0.2632861 \\
\hline n3850-m-49r & 0.3571133 & 0.0789116 & 0.1981388 & 0.0535409 \\
\hline n3850-m-48 & 0.3280262 & 0.1621888 & 0.0251607 & 0.0704549 \\
\hline n3850-m-47 & 0.3123631 & 0.1654724 & 0.0172684 & 0.0676465 \\
\hline n3850-m-52 & 0.3032533 & 0.2633625 & 0.016613 & 0.1007222 \\
\hline n3850-m-58 & 0.2963842 & 0.1703757 & 0.0153554 & 0.1278908 \\
\hline n3850-m-58r & 0.3257341 & 0.185458 & 0.0170295 & 0.0950976 \\
\hline n3850-m-78 & 0.3016942 & 0.2450947 & 0.0506154 & 0.220575 \\
\hline n3850-m-32 & 0.3076245 & 0.3130608 & 0.0179538 & 0.0929182 \\
\hline $\mathrm{n} 3850-\mathrm{m}-73$ & 0.3217027 & 0.4047196 & 0.0490527 & 0.1390517 \\
\hline n3850-m-30 & 0.3070775 & 0.2250453 & 0.0197682 & 0.0765633 \\
\hline n3850-m-66 & 0.2784237 & 0.2846996 & 0.0180125 & 0.2662647 \\
\hline
\end{tabular}

${ }^{1}$ n3852, n3847, and n3850 are the NordSIMS laboratory numbers for sample identification. ' $r$ ' refers to rim domain and 'b' to duplicate analyses.

${ }^{2}$ Values corrected for common $\mathrm{Pb}$.

positive Ce and negative Eu anomalies and steep HREE patterns. Three analyses are unusually enriched in LREEs (fig. 5B), possibly due to the presence of unobserved micro-inclusions, such as monazite. 

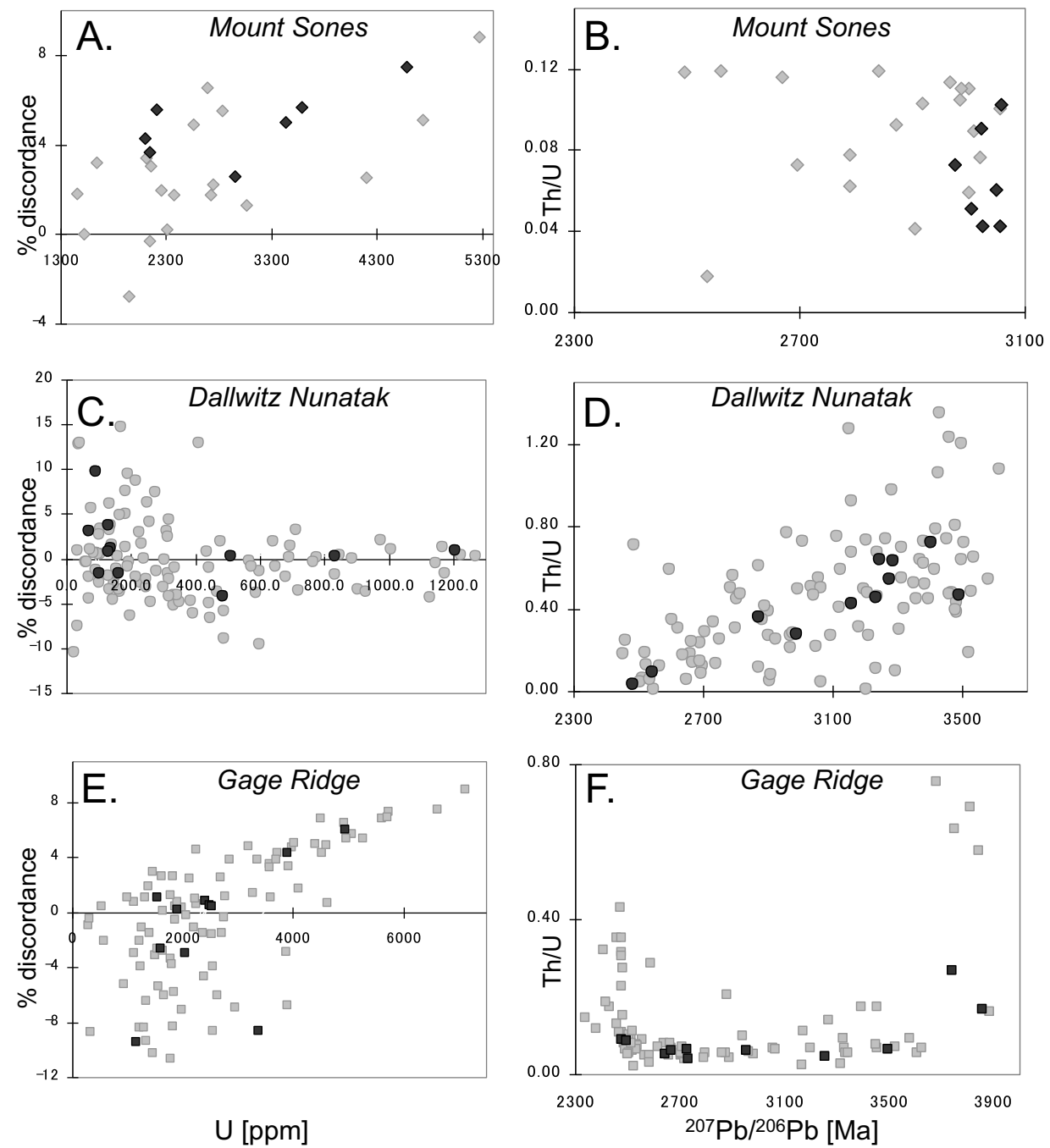

Fig. 3. Geochemical plots of samples from the Napier Complex: (A), (C), (E) \% discordance versus uranium content for Mount Sones, Dallwitz Nunatak and Gage Ridge samples, respectively; values $>0=$ reversely discordant data; (B), (D), (F) Th/U ratio versus ${ }^{207} \mathrm{~Pb} /{ }^{206} \mathrm{~Pb}$ age for each sample. Diamonds $=\mathrm{Mt}$ Sones, circles = Dallwitz Nunatak, squares = Gage Ridge; gray symbols $=$ analyses of the inner parts of grains; black symbols $=$ analyses in the outer parts of grains.

Zircon grain number 44 was selected for analysis by Raman spectroscopy, following ion probe imaging. The variation in Raman spectral characteristics of the zircon $\mathrm{n}_{3}$ $\left(\mathrm{SiO}_{4}\right)$ anti-symmetric Raman band near $1008 \mathrm{~cm}^{-1}$ is shown in figure 6 (A-C). Intensity (fig. 6A), shift (fig. 6B) and FWHM (Full Width at Half Maximum, fig. 6C) of this Raman band is strongly dependent on crystallinity (Nasdala and others, 1995). With increasing radiation damage the $\mathrm{n}_{3}\left(\mathrm{SiO}_{4}\right)$ band shifts from around $1008 \mathrm{~cm}^{-1}$ down to around $994 \mathrm{~cm}^{-1}$ and the FWHM increases from about 5 to up to $35 \mathrm{~cm}^{-1}$. A loss in Raman intensity can also be observed with increasing lattice damage. The Raman map of this grain shows a clear correlation between regions that are dark in CL 
TABLE 5

Oxygen isotope data for zircon grains from Mt Sones, Dallwitz Nunatak and Gage Ridge samples

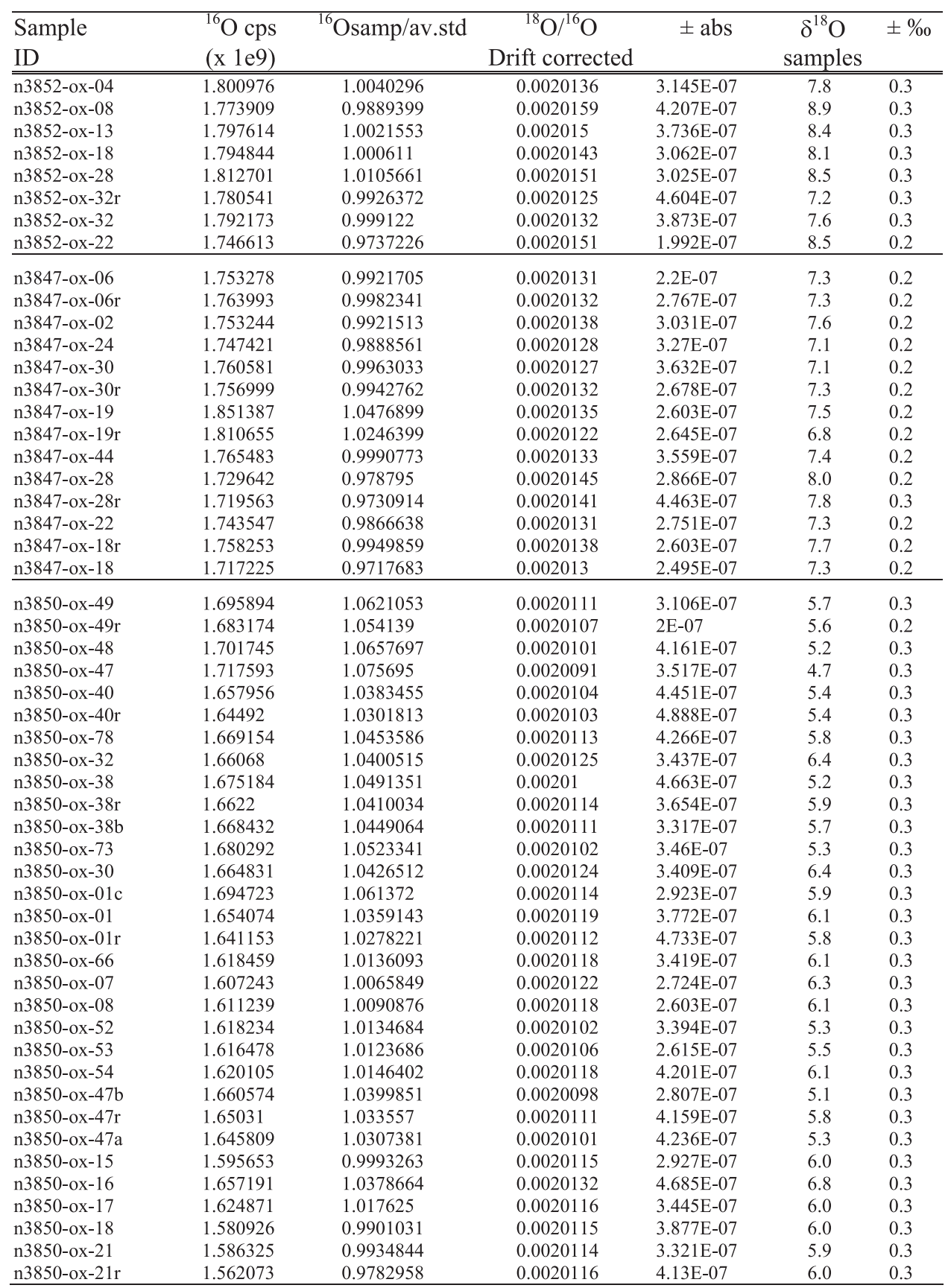

${ }^{1} \mathrm{n} 3852, \mathrm{n} 3847$, and n3850 are the NordSIMS laboratory numbers for sample identification. ' $r$ ' refers to rim domain, 'c' refers to central domain, and 'a' and ' $b$ ' to duplicate analyses.

${ }^{2}$ Values corrected for common $\mathrm{Pb}$. 

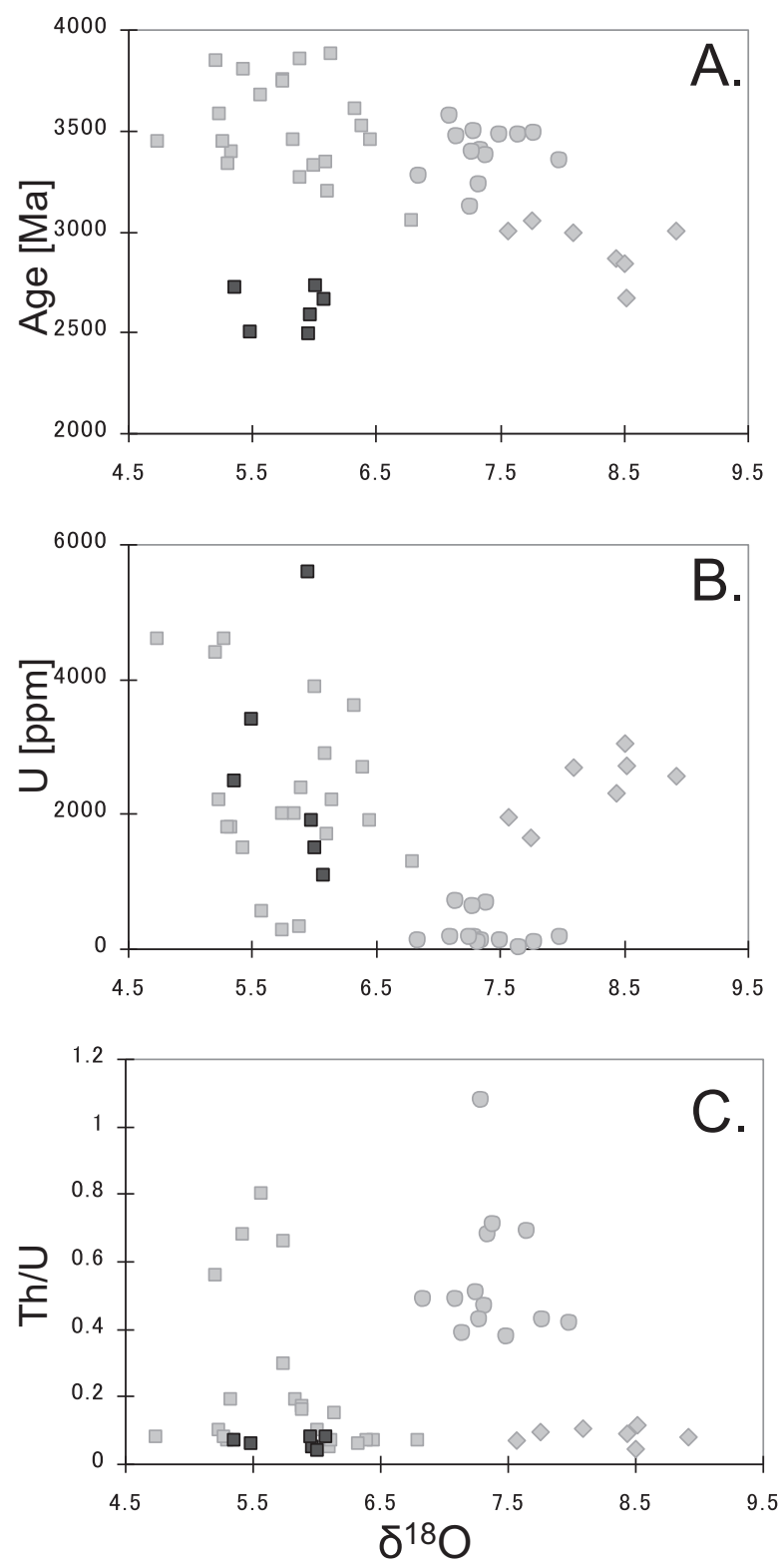

$\diamond$ Mount Sones $\circ$ Dallwitz Nunatak

$\square$ Gage Ridge zircon inner parts

- Gage Ridge zircon outer parts

Fig. 4. Oxygen data for selected zircon grains from the Napier Complex plotted against (A) ${ }^{207} \mathrm{~Pb} /{ }^{206} \mathrm{~Pb}$ ages, (B) U content and (C) Th/U ratio. Gray symbols = analyses of the inner parts of grains; black symbols $=$ analyses of the outer parts of grains. 
TABLE 6

SIMS REE data for zircons from Mt Sones, Dallwitz Nunatak, and Gage Ridge samples

\begin{tabular}{|c|c|c|c|c|c|c|c|c|c|c|c|c|}
\hline Sample \# & $\mathrm{Y}$ & Hf & $\mathrm{La}$ & $\mathrm{Ce}$ & $\operatorname{Pr}$ & $\mathrm{Nd}$ & $\mathrm{Sm}$ & $\mathrm{Eu}$ & Gd & Dy & Er & $\mathrm{Yb}$ \\
\hline n3852ree_04 & 520 & 9803 & 0.00 & 3.72 & 0.03 & 0.64 & 1.93 & 0.14 & 10.05 & 44.8 & 64.7 & 121.8 \\
\hline n3852ree_08 & 957 & 12003 & 1.29 & 17.93 & 3.04 & 22.55 & 11.09 & 0.86 & 20.03 & 79.1 & 128.9 & 207.5 \\
\hline n3852ree_13 & 447 & 10529 & 0.02 & 3.43 & 0.05 & 0.60 & 1.57 & 0.17 & 8.10 & 39.2 & 57.3 & 103.0 \\
\hline n3852ree_22 & 665 & 10152 & 0.00 & 3.90 & 0.03 & 0.84 & 2.52 & 0.29 & 10.34 & 57.0 & 84.6 & 159.1 \\
\hline n3852ree_36 & 506 & 10465 & 0.00 & 5.13 & 0.05 & 1.24 & 2.95 & 0.21 & 10.72 & 38.6 & 57.6 & 107.0 \\
\hline n3852ree_32c & 450 & 9945 & 0.07 & 4.71 & 0.09 & 0.55 & 1.90 & 0.15 & 7.69 & 33.1 & 48.5 & 83.5 \\
\hline n3852ree_32r & 2234 & 13246 & 1.75 & 14.22 & 1.98 & 11.66 & 5.66 & 0.52 & 27.44 & 164.9 & 314.8 & 568.8 \\
\hline n3852ree_18 & 1305 & 11422 & 0.57 & 7.13 & 0.81 & 4.73 & 2.66 & 0.20 & 11.90 & 102.2 & 219.2 & 511.6 \\
\hline n3852ree_28 & 483 & 10170 & 0.00 & 4.37 & 0.03 & 0.77 & 2.15 & 0.15 & 9.21 & 38.4 & 62.7 & 112.9 \\
\hline n3852ree_28r & 1369 & 13569 & 0.41 & 7.94 & 1.08 & 8.60 & 6.52 & 0.52 & 20.06 & 117.4 & 199.0 & 362.7 \\
\hline 915-ree_mt970 & 141 & 5199 & 0.00 & 3.70 & 0.02 & 0.36 & 0.64 & 0.29 & 1.97 & 12.0 & 25.4 & 60.7 \\
\hline n3847ree_52 & 1760 & 7635 & 0.03 & 19.42 & 0.42 & 5.98 & 8.73 & 2.33 & 44.57 & 177.6 & 266.8 & 464.5 \\
\hline n3847ree_51 & 866 & 11309 & 0.00 & 8.01 & 0.01 & 0.51 & 1.45 & 0.72 & 9.81 & 68.5 & 129.6 & 276.1 \\
\hline n3847ree_44 & 2112 & 10032 & 0.18 & 34.12 & 0.23 & 2.62 & 5.48 & 0.35 & 32.22 & 172.9 & 317.8 & 570.4 \\
\hline n3847ree_43 & 2281 & 7623 & 0.03 & 22.20 & 0.14 & 3.13 & 6.32 & 1.29 & 34.36 & 191.0 & 339.7 & 615.6 \\
\hline n3847ree_63 & 1720 & 11330 & 0.22 & 10.93 & 0.11 & 1.24 & 3.30 & 0.66 & 25.41 & 157.7 & 277.7 & 538.4 \\
\hline n3847ree_33 & 578 & 10849 & 0.08 & 10.60 & 0.06 & 0.82 & 1.61 & 0.50 & 8.90 & 51.4 & 99.8 & 247.2 \\
\hline n3847ree_32 & 885 & 9186 & 0.00 & 11.35 & 0.05 & 0.96 & 2.32 & 0.13 & 13.72 & 74.0 & 135.5 & 228.5 \\
\hline n3847ree_30c & 1402 & 7823 & 0.01 & 14.52 & 0.12 & 2.27 & 4.66 & 1.00 & 24.19 & 121.9 & 217.2 & 388.9 \\
\hline n3847ree_30r & 980 & 7843 & 0.00 & 14.38 & 0.08 & 1.69 & 3.39 & 0.78 & 16.46 & 91.4 & 156.4 & 277.4 \\
\hline n3847ree_42 & 1492 & 9010 & 2240.90 & 4584.77 & 451.56 & 1575.68 & 344.36 & 14.89 & 100.92 & 118.4 & 211.8 & 357.2 \\
\hline n3847ree_83 & 295 & 11893 & 0.00 & 7.32 & 0.02 & 0.66 & 1.28 & 0.33 & 6.05 & 26.6 & 46.6 & 114.6 \\
\hline n3847ree_24 & 778 & 10766 & 0.01 & 18.87 & 0.05 & 0.94 & 2.47 & 0.11 & 13.15 & 71.9 & 115.3 & 186.9 \\
\hline n3847ree_22 & 1948 & 8248 & 0.00 & 14.76 & 0.08 & 2.13 & 5.29 & 0.77 & 34.14 & 185.8 & 298.5 & 471.7 \\
\hline n3847ree_21 & 1016 & 7690 & 0.00 & 6.21 & 0.05 & 1.40 & 3.31 & 1.05 & 19.59 & 104.0 & 159.0 & 274.8 \\
\hline n3847ree_19c & 2079 & 10461 & 1817.07 & 4329.56 & 596.99 & 2253.19 & 596.10 & 10.03 & 944.00 & 531.5 & 430.3 & 603.0 \\
\hline n3847ree_19r & 1681 & 9399 & 0.01 & 30.31 & 0.11 & 2.20 & 4.32 & 1.42 & 29.65 & 150.2 & 257.1 & 476.3 \\
\hline n3847ree_18c & 3350 & 7113 & 0.02 & 10.56 & 0.13 & 3.51 & 7.96 & 1.22 & 52.91 & 296.6 & 522.5 & 880.2 \\
\hline n3847ree_18r & 4546 & 8280 & 0.00 & 32.30 & 0.12 & 3.55 & 9.79 & 1.47 & 89.18 & 489.5 & 717.7 & 1089.6 \\
\hline n3847ree_13 & 1019 & 11306 & 0.00 & 8.27 & 0.03 & 0.81 & 2.00 & 0.65 & 12.85 & 84.8 & 177.0 & 424.1 \\
\hline n3847ree_90 & 1342 & 9854 & 0.47 & 32.17 & 0.39 & 2.86 & 3.91 & 1.00 & 20.10 & 100.9 & 192.6 & 419.4 \\
\hline n3847ree_92 & 581 & 13144 & 0.03 & 2.32 & 0.00 & 0.45 & 0.58 & 0.13 & 1.37 & 25.4 & 110.1 & 347.4 \\
\hline n3847ree_08 & 689 & 10078 & 0.05 & 17.64 & 0.05 & 1.13 & 2.54 & 1.05 & 14.56 & 60.6 & 100.6 & 211.5 \\
\hline n3847ree_07 & 2240 & 8957 & 2950.91 & 12887.64 & 1174.53 & 5546.72 & 1246.46 & 21.34 & 2239.75 & 967.6 & 559.0 & 557.6 \\
\hline n3847ree_06c & 721 & 9188 & 0.01 & 27.60 & 0.07 & 1.47 & 2.83 & 0.61 & 14.08 & 63.0 & 107.6 & 191.3 \\
\hline n3847ree_06r & 360 & 10825 & 0.00 & 21.93 & 0.03 & 0.51 & 1.21 & 0.24 & 5.47 & 27.7 & 55.2 & 121.5 \\
\hline n3847ree_04 & 721 & 8722 & 0.01 & 8.04 & 0.14 & 2.08 & 3.25 & 0.83 & 17.47 & 72.5 & 117.6 & 236.0 \\
\hline n3847ree_02 & 2827 & 8475 & 0.00 & 18.26 & 0.12 & 3.17 & 7.17 & 2.63 & 50.96 & 282.6 & 460.4 & 763.5 \\
\hline n3847ree_02b & 2013 & 8744 & 0.00 & 13.00 & 0.07 & 2.01 & 4.79 & 1.61 & 34.81 & 186.8 & 314.8 & 539.8 \\
\hline 915-ree mt972 & 124 & 5541 & 0.00 & 3.66 & 0.03 & 0.40 & 0.80 & 0.38 & 1.78 & 10.6 & 22.3 & 54.1 \\
\hline n3850ree_38c & 2239 & 8953 & 0.37 & 16.24 & 0.25 & 2.16 & 4.33 & 1.01 & 30.09 & 171.3 & 335.7 & 663.8 \\
\hline n3850ree_38b & 1583 & 9571 & 0.08 & 13.88 & 0.07 & 1.28 & 3.23 & 0.49 & 23.64 & 132.9 & 238.6 & 489.3 \\
\hline n3850ree_49c & 2218 & 7278 & 0.14 & 22.30 & 0.70 & 10.12 & 15.75 & 4.68 & 63.22 & 212.5 & 315.4 & 523.7 \\
\hline n3850ree_49r & 1552 & 7670 & 0.27 & 20.02 & 0.20 & 2.29 & 3.60 & 1.04 & 22.61 & 129.5 & 242.9 & 425.6 \\
\hline n3850ree_48 & 891 & 16605 & 0.01 & 6.15 & 0.03 & 0.69 & 2.43 & 0.01 & 18.14 & 92.4 & 121.8 & 193.7 \\
\hline n3850ree_47c & 3568 & 18145 & 0.04 & 6.98 & 0.04 & 0.78 & 3.45 & 0.04 & 38.35 & 346.0 & 425.9 & 502.1 \\
\hline n3850ree_47r & 1512 & 15907 & 1.47 & 8.94 & 0.66 & 2.18 & 2.04 & 0.27 & 14.79 & 134.1 & 177.2 & 215.8 \\
\hline n3850ree_78 & 491 & 9457 & 0.20 & 3.27 & 0.13 & 0.59 & 0.66 & 0.06 & 3.00 & 28.5 & 85.7 & 273.0 \\
\hline n3850ree_40 & 613 & 8279 & 0.02 & 7.19 & 0.07 & 1.32 & 3.09 & 1.00 & 17.01 & 62.8 & 87.9 & 154.0 \\
\hline n3850ree_40r & 577 & 7362 & 3.70 & 4.83 & 0.43 & 2.93 & 5.10 & 1.35 & 5.83 & 43.6 & 85.9 & 191.2 \\
\hline n3850ree_32 & 1018 & 15992 & 0.05 & 4.74 & 0.03 & 0.45 & 1.98 & 0.02 & 16.89 & 90.3 & 109.9 & 134.4 \\
\hline n3850ree_73 & 1843 & 12474 & 1.94 & 14.34 & 0.77 & 3.39 & 3.30 & 0.27 & 19.31 & 140.6 & 272.2 & 486.0 \\
\hline n3850ree_30 & 1009 & 14863 & 0.01 & 4.38 & 0.02 & 0.49 & 2.21 & 0.01 & 17.22 & 91.6 & 97.6 & 115.3 \\
\hline n3850ree_01 & 1047 & 10015 & 0.00 & 6.54 & 0.03 & 0.68 & 2.15 & 0.15 & 13.45 & 86.6 & 159.7 & 300.9 \\
\hline n3850ree_01b & 1007 & 10213 & 0.15 & 6.73 & 0.09 & 0.78 & 1.71 & 0.50 & 11.69 & 82.9 & 151.7 & 271.0 \\
\hline n3850ree_01r & 2003 & 8846 & 0.20 & 10.77 & 0.17 & 1.85 & 3.61 & 0.63 & 22.80 & 139.8 & 295.9 & 616.4 \\
\hline n3850ree_66 & 1403 & 13716 & 0.14 & 4.25 & 0.08 & 0.70 & 1.22 & 0.02 & 8.36 & 77.6 & 269.8 & 729.3 \\
\hline n3850ree_08 & 1000 & 15198 & 0.03 & 3.58 & 0.03 & 0.50 & 1.66 & 0.02 & 10.06 & 75.7 & 154.6 & 401.4 \\
\hline n3850ree_07 & 3336 & 18990 & 0.02 & 5.06 & 0.02 & 0.50 & 1.96 & 0.03 & 21.99 & 240.9 & 564.7 & 1131.1 \\
\hline 915-ree_mt975 & 170 & 5514 & 0.00 & 3.95 & 0.02 & 0.37 & 0.69 & 0.34 & 2.92 & 14.6 & 30.0 & 70.0 \\
\hline
\end{tabular}

${ }^{1} \mathrm{n} 3852, \mathrm{n} 3847$, and n3850 are the NordSIMS laboratory numbers for sample identification. ' $r$ ' refers to rim domain, 'c' to central domain, and 'b' to duplicate analyses.

${ }^{2}$ Values corrected for common $\mathrm{Pb}$. 


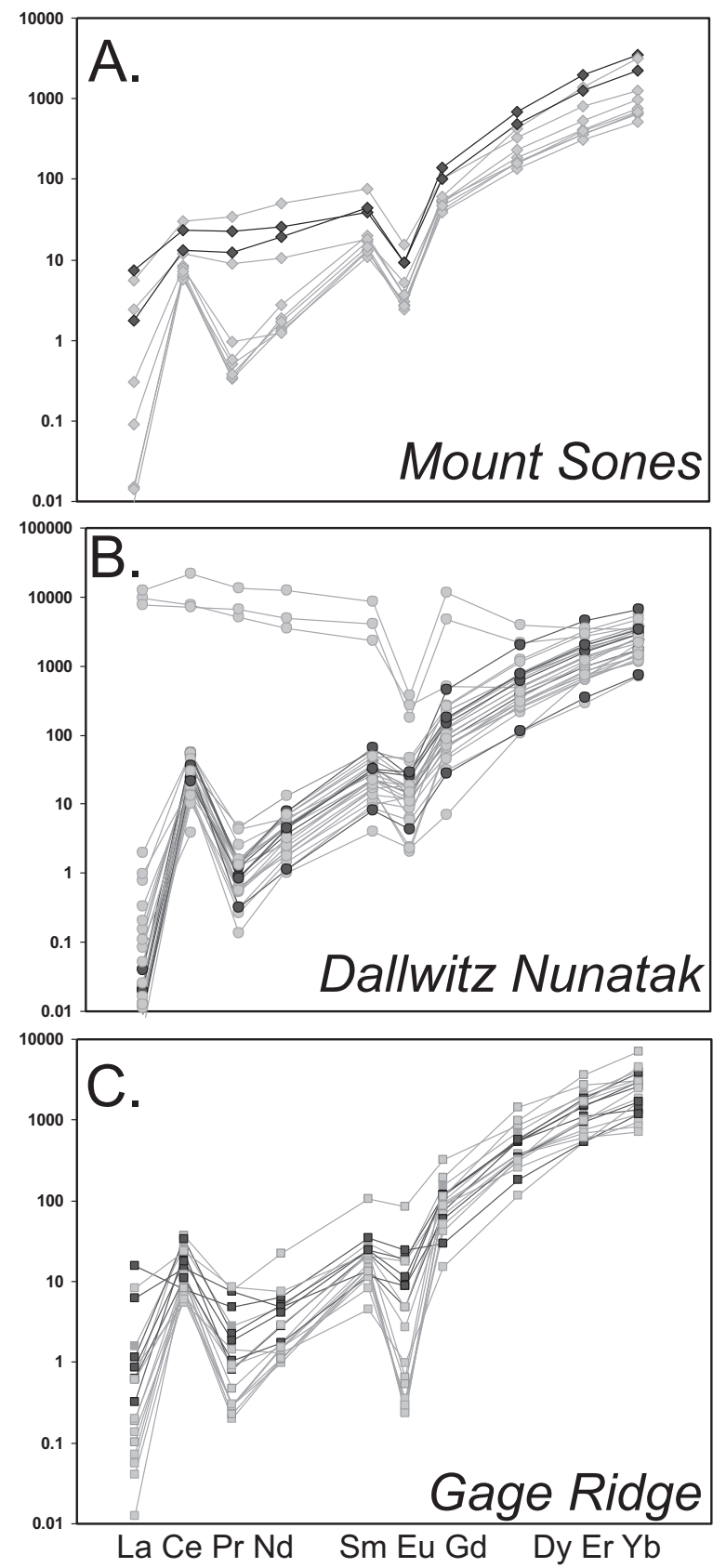

Fig. 5. Chondrite-normalized REE plots of zircons from (A) Mount Sones, (B) Dallwitz Nunatak and (C) Gage Ridge; gray symbols = analyses of the inner parts of grains; black symbols = analyses of the outer parts of grains.

with low Raman intensities and shifts to lower wave numbers, as well as increasing FWHM of the $\mathrm{n}_{3}\left(\mathrm{SiO}_{4}\right)$ band. These less crystalline parts contain higher amounts of $\mathrm{U}$ and Th. 


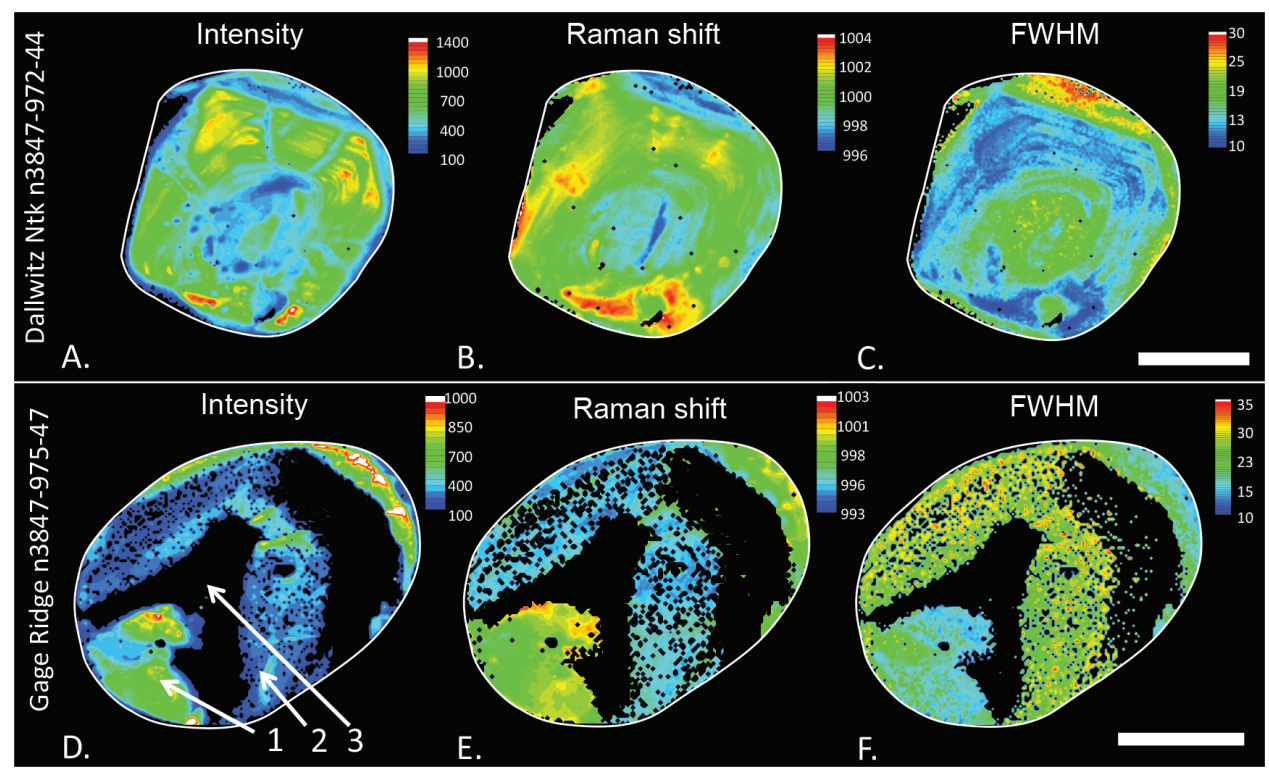

Fig. 6. Raman spectroscopy maps of the two analyzed zircon grains: (A), (B), (C): Dallwitz Nunatak, grain n3847-44; (D), (E), (F): Gage Ridge, grain n3850-47. In (D) Zone 1 = moderately radiation damaged area, 2 amorphous area, and $3=$ glassy area with retained zircon composition. Intensity is given in arbitrary units; Raman shift and FWHM are in $\mathrm{cm}^{-1}$.

\section{Sample 16178-2, n3850-975; Gage Ridge, Orthogneiss}

Similar to zircons from the Mount Sones paragneiss, this sample contains only grains that are dark in CL. A total of $98 \mathrm{U}-\mathrm{Pb}$ analyses were performed on 86 grains and the data record the oldest age obtained in this study of $3883 \pm 11 \mathrm{Ma}$. A discordia through the data, anchored at $2500 \pm 50 \mathrm{Ma}$, yields an upper intercept age of $3680 \pm 53$ Ma (fig. 2C). These zircons have the widest range of $U$ contents, with a maximum of $7122 \mathrm{ppm}$. There is a small sub-set of grains with distinctly lower $\mathrm{U}$ contents of between 285 to $555 \mathrm{ppm}$. Thorium values are also variable and range from 39 to $2470 \mathrm{ppm}$, with $\mathrm{Th} / \mathrm{U}$ ratios of 0.02 to 0.76 . Multi-collector data (table 4) from 18 grains give a weighted mean ${ }^{207} \mathrm{~Pb} /{ }^{206} \mathrm{~Pb}$ age of $3768 \pm 76 \mathrm{Ma}$. There is a broad positive correlation between $U$ content and percentage discordance (fig. 3E). However, there is no correlation between age and $\mathrm{Th} / \mathrm{U}$ ratio (fig. $3 \mathrm{~F}$ ).

Oxygen isotope analyses of 31 spots on 22 grains gave much lower values than for the previous two samples (fig. 4), with a range of $\delta^{18} \mathrm{O}$ between 4.7 to 6.8 permil, and an average of $5.8 \pm 0.1$ permil (table 5). There is no correlation between $\delta^{18} \mathrm{O}$ and ${ }^{207} \mathrm{~Pb} /{ }^{206} \mathrm{~Pb}$ age, $\mathrm{U}$ content, or $\mathrm{Th} / \mathrm{U}$ (fig. 4). The REE trends are similar to the previous samples, with three analyses showing slightly elevated LREE (fig. 5C).

Raman investigations of grain number 47 confirmed that areas dark in CL correspond to lower crystallinity (fig. 6). There are a few inclusions of quartz and several unidentified minerals in the zircon grain. The Raman map shows three different areas (figs. 6D, 6E and 6F): (1) a moderately radiation damaged zone with FWHM values for the $\mathrm{n}_{3}\left(\mathrm{SiO}_{4}\right)$ band of $c a .18 \mathrm{~cm}^{-1}$ and a Raman shift of $c a .998 \mathrm{~cm}^{-1}$, (2) a strongly radiation damaged area with FWHM values at $c a .25 \mathrm{~cm}^{-1}$ along with a Raman shift at $c a .996 \mathrm{~cm}^{-1}$, and (3) an amorphous area that does not yield any Raman signal. The latter glassy area, however, has retained the stoichiometric composition of zircon, and has similar $\mathrm{Zr}$ and $\mathrm{Si}$ contents to the less damaged areas. The area mapped 
by Raman is the same as that mapped for element concentration by Kusiak and others (2013; fig. 3). The less crystalline parts host higher amounts of $U$ and Th. Although $\mathrm{Pb}$ concentrations are higher in the U-rich, less crystalline areas, the distribution of $\mathrm{Pb}$ is consistently patchy on a smaller scale throughout the mapped areas.

SCANNING ION IMAGING (SII)

In order to address the issue of reverse discordance, following spot analysis, areas of $70 \mu \mathrm{m} \times 70 \mu \mathrm{m}$ in selected grains were imaged (scanning ion imaging; SII) using a $c a .2 \mu \mathrm{m}$ rastered primary beam. This allows both element and isotope variations to be evaluated.

Two zircon grains from Mount Sones were imaged: grain 28 with an age of $2839 \pm 8$ $\mathrm{Ma}$ and a $\mathrm{U}$ content of $3058 \mathrm{ppm}$ (fig. 7A), and grain 04 with an age of $3056 \pm 7 \mathrm{Ma}$ and a $\mathrm{U}$ content of $1641 \mathrm{ppm}$ (fig. 7B). Both grains have a $\mathrm{Th} / \mathrm{U}$ ratio of 0.1 . A single grain from Dallwitz Nunatak with an age of $3578 \pm 23 \mathrm{Ma}$, a U content of $165 \mathrm{ppm}$, and a $\mathrm{Th} / \mathrm{U}$ ratio of 0.49 was selected for imaging (fig. $7 \mathrm{C}$ ). This zircon has the lowest $\mathrm{U}$ content amongst the imaged grains. The Gage Ridge sample is represented by the oldest analyzed zircon with an age of $3883 \pm 11 \mathrm{Ma}$. This grain contains $2247 \mathrm{ppm}$ of U and has a $\mathrm{Th} / \mathrm{U}$ ratio of 0.16 (fig. 7D). The Hf contents of all imaged grains are uniformly distributed (fig. 7).

Both grains from Mount Sones have low CL responses, but ion images reveal variable distribution of different elements. Uranium, thorium and yttrium define oscillatory zoning patterns, characteristic of magmatic zircons. Lead displays a patchy distribution, unrelated to any cracks or inclusions in the grains (fig. 7). The grains from Dallwitz Nunatak and Gage Ridge do not exhibit any zonation in U or Y. However, $\mathrm{Pb}$ patchiness was identified in both mapped zircons (fig. 7), independent of the $\mathrm{U}$ content, age, and $\mathrm{Th} / \mathrm{U}$ ratio.

Multi-collector lead isotope images, which show evidence of patchiness for both ${ }^{206} \mathrm{~Pb}$ and ${ }^{207} \mathrm{~Pb}$, were used to provide maps of the distribution of ${ }^{207} \mathrm{~Pb} /{ }^{206} \mathrm{~Pb}$ (fig. 8) for two grains; the youngest and the oldest imaged in this study. Elliptical areas were selected using the WinImage software, with areas measuring $c a .123 \mu \mathrm{m}^{2}$ in order to mimic the size of typical SIMS analytical spots, and 100 sites were randomly placed across the two images to test for variations in ${ }^{207} \mathrm{~Pb} /{ }^{206} \mathrm{~Pb}$ ages. Using the area definition tool, ${ }^{207} \mathrm{~Pb} /{ }^{206} \mathrm{~Pb}$ ages (common $\mathrm{Pb}$ corrected) were then calculated for those areas. Targeted areas in both grains yield a broad range of calculated ages with up to $0.5 \mathrm{Ma}$ difference. The zircon grain from Mount Sones with a spot age of $2839 \pm 8$ Ma, yields ${ }^{207} \mathrm{~Pb} /{ }^{206} \mathrm{~Pb}$ ages ranging between $2599 \mathrm{Ma}$, for the darkest region, up to $3037 \mathrm{Ma}$ for the brightest (fig. 8B). The selected grain from Gage Ridge is the oldest analyzed grain, with a SIMS spot age of $3883 \pm 11 \mathrm{Ma}$. The ${ }^{207} \mathrm{~Pb} /{ }^{206} \mathrm{~Pb}$ image map shows the location of all 100 SIMS-sized spots (around $20 \mu \mathrm{m}$ across) randomly distributed across the scanned ion image (fig. 8D). The youngest age is $3527 \mathrm{Ma}$, whereas the oldest is $4025 \mathrm{Ma}$. The oldest (Hadean) dates are not "real" ages, but artifacts of radiogenic $\mathrm{Pb}$ mobilization, leading to an apparent increase in the magmatic age of the crystal. The youngest ages closely approximate the time of disturbance of the crystal. Although there is a variation of 500 million years in the calculated dates (fig. 8D), the robust mean age of all 100 sites is $3866 \pm 15 \mathrm{Ma}$ (at $95 \%$ confidence, Tukey's biweight mean), which is within error of the SIMS spot analysis. However, if other sites had been selected for in-situ SIMS analysis, a spurious age could have been obtained for this grain.

DISCUSSION

Timing of Geological Events in the Napier Complex

The zircons from the Mount Sones paragneiss were significantly younger than those in the other two samples, yielding an upper intercept age of 2810 $\pm 45 \mathrm{Ma}$. 
A.
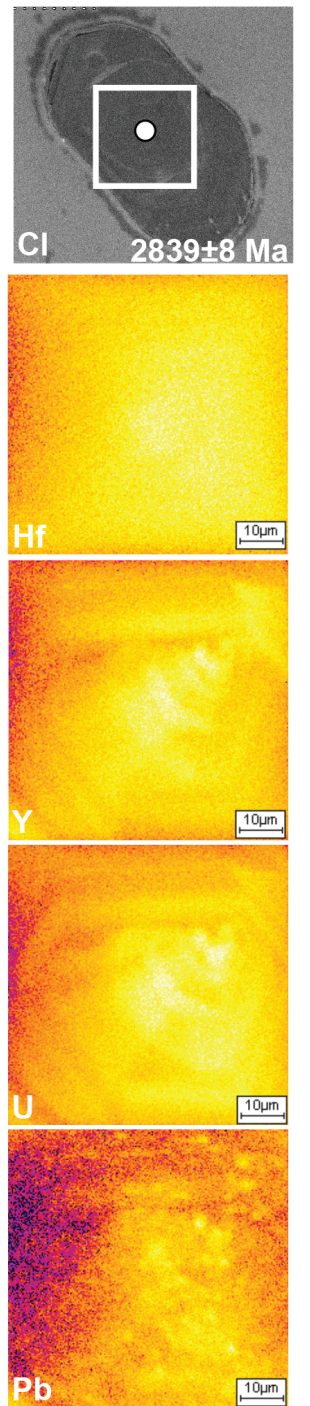

B.
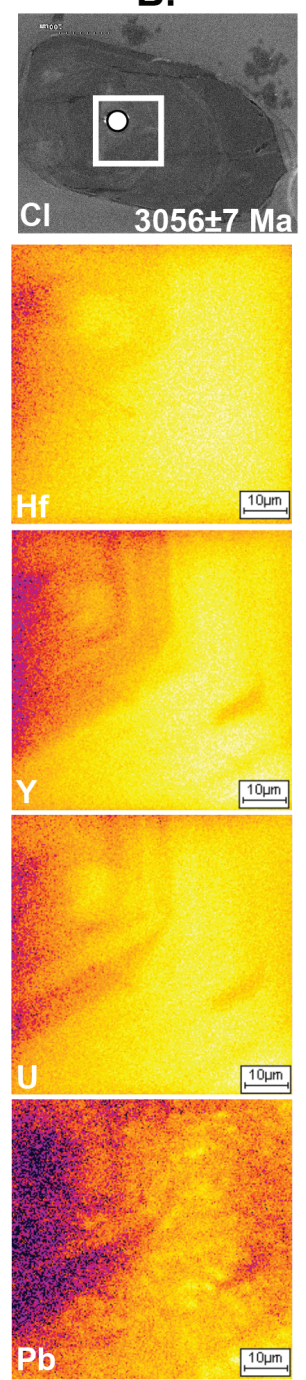

C.
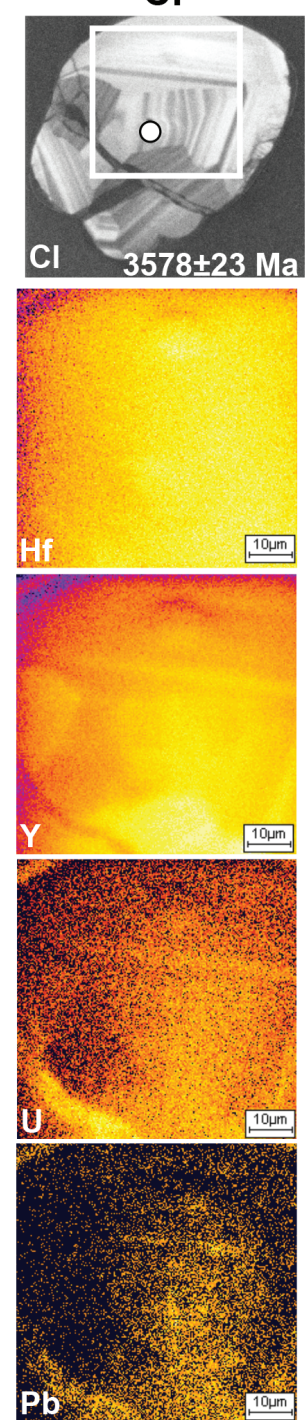

D.
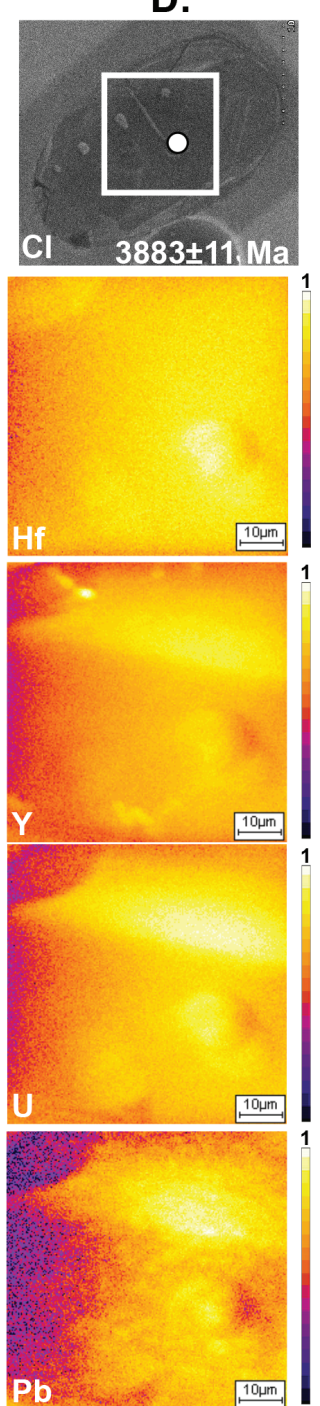

Fig. 7. CL and scanning ion images showing relative intensity of Hf, Y, U and Th; (A) Mount Sones, grain n3852-28, (B) Mount Sones, grain n3852-04, (C) Dallwitz Nunatak, grain n3847-30, (D) Gage Ridge, grain n3850-01; White squares on CL images $=$ SII areas of $70 \times 70 \mu \mathrm{m}$; white circles are spot analyses with ${ }^{207} \mathrm{~Pb} /{ }^{206} \mathrm{~Pb}$ age. The color-scale bars are relative intensity (they do not correspond precisely to ppm).

Excluding a few younger analyses that may have experienced $\mathrm{Pb}$ loss at $2.5 \mathrm{Ga}$, the majority of grains are reversely discordant and relatively U-rich and Th-poor, with uniform compositions and no evidence of oscillatory zoning or other features typical of igneous zircon. Zircon grains of similar characteristics in an orthogneiss from nearby Dallwitz Nunatak, and with an upper intercept age of $2842 \pm 16 \mathrm{Ma}$, were identified by Kelly and Harley (2005) as being of metamorphic origin. We suggest that the $c a .2810$ Ma zircons from Mount Sones are also metamorphic in origin, with two possible relationships to the host metasedimentary rock: 1) the host was metamorphosed at 2.8 

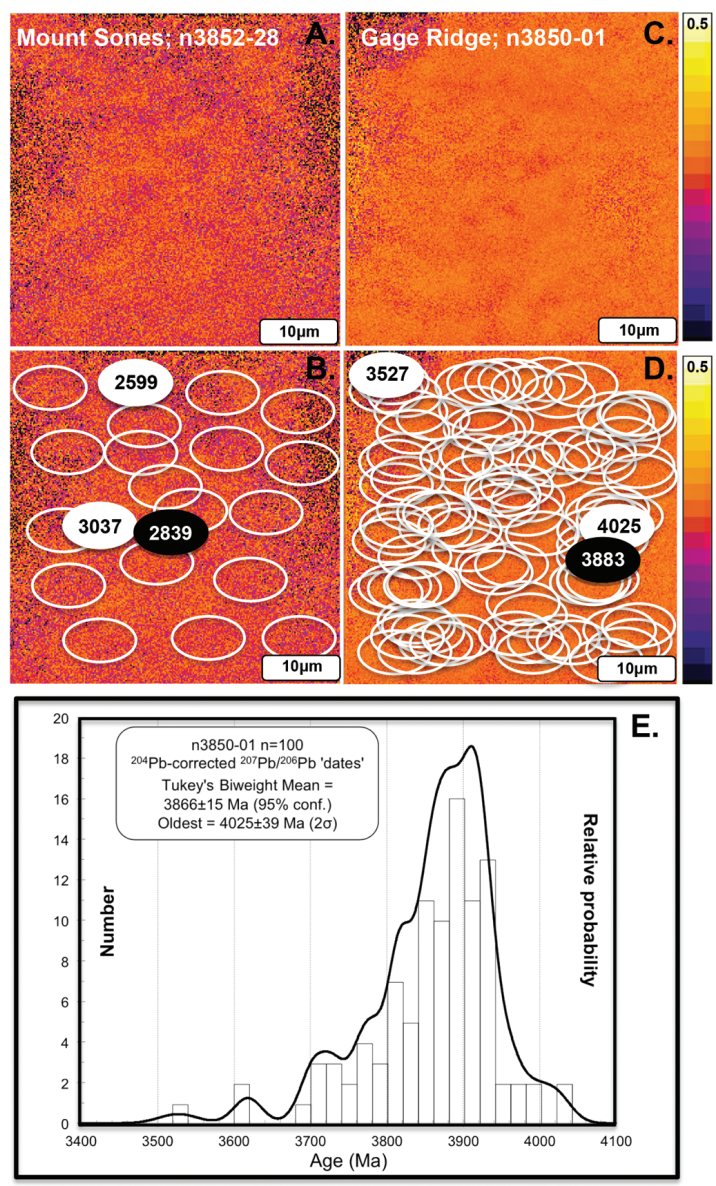

Fig. 8. ${ }^{207} \mathrm{~Pb} /{ }^{206} \mathrm{~Pb}$ ratio images. (A), (B) Mount Sones, grain n3852-28, (C), (D) Gage Ridge, grain $\mathrm{n} 3850-01$. Ellipses show the areas used for ${ }^{207} \mathrm{~Pb} /{ }^{206} \mathrm{~Pb}$ age calculation and include the oldest and youngest values (solid white ellipses) and location of SIMS spot (solid black ellipses). For clarity, on (B) not all 100 areas are shown, (E) Relative probability of all data from grain n3850-01, Gage Ridge.

$\mathrm{Ga}$, or 2) the host was deposited after $2.8 \mathrm{Ga}$ and includes detrital zircons derived from the erosion of $2.8 \mathrm{Ga}$ granulite. Although the latter interpretation is consistent with the deposition of the paragneiss protolith being later than $2.6 \mathrm{Ga}$, as suggested by Horie and others (2012), unlike their samples, there is a lack of concordant ages younger than $2.8 \mathrm{Ga}$ in the Mount Sones sample. This is consistent with the former interpretation of the sample as a sedimentary rock metamorphosed at both $2.8 \mathrm{Ga}$ and $2.5 \mathrm{Ga}$.

The paragneiss from Dallwitz Nunatak records U-Pb ages that mostly scatter along

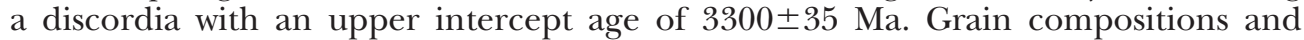
structures are more diverse than in the Mount Sones sample and lack a component of $2.8 \mathrm{Ga}$ zircon that could be clearly identified as metamorphic in origin. The low precision of many analyses is due to irregular $\mathrm{Pb}$ count rates during analysis, itself caused by the redistribution of $\mathrm{Pb}$ into micro-domains, most likely as a result of the 2.5 Ga metamorphic event. As a result, we consider the data to represent detrital zircon from sources that formed between $3550 \mathrm{Ma}$ and $2750 \mathrm{Ma}$, which are the approximate ages of the oldest and youngest zircons that are concordant within 2 sigma. 
The Gage Ridge orthogneiss sample contains four age groups. The youngest group at $c a$. $2.5 \mathrm{Ga}$ was obtained from zircon grains and rims with relatively low $\mathrm{Th} / \mathrm{U}$ (0.02-0.43) and high U (1000-7000 ppm) contents, attributable to growth during metamorphism. The next youngest group consists of a broadly linear array of discordant data between $3.8 \mathrm{Ga}$ and $2.5 \mathrm{Ga}$. These are interpreted as older zircon that variably lost radiogenic $\mathrm{Pb}$ during $c a .2 .5 \mathrm{Ga}$ metamorphism. A distinct group of zircons with relatively high $\mathrm{Th} / \mathrm{U}(0.6-0.8)$ preserve the oldest isotopic signatures, and on a discordia chord anchored at $2500 \pm 50 \mathrm{Ma}$ (a conservative estimate of the timing of metamorphism), define an upper intercept age of $3774 \pm 36 \mathrm{Ma}(\mathrm{n}=7)$. This is similar to the zircon age obtained by Kelly and Harley (2005), which they interpreted as the time of formation of the magmatic protolith to the Gage Ridge orthogneiss. However, there is a fourth group of data that do not lie along this chord, but spread closer to concordia between 3.6 and $3.3 \mathrm{Ga}$. These zircons differ in composition from the oldest group, with higher $\mathrm{U}$ and lower $\mathrm{Th} / \mathrm{U}$ values. If this group represents a distinct stage of zircon growth between events at $3.8 \mathrm{Ga}$ and $2.5 \mathrm{Ga}$, then a number of interpretations are possible. Such growth could have occurred during an as yet unrecognized metamorphic event, in which case the $c a .3 .8 \mathrm{Ga}$ protolith has undergone high-grade metamorphism twice; alternatively, the zircon could be magmatic, and possibly related to $c a .3 .3 \mathrm{Ga}$ magmatism identified by Hokada and others (2003) at Mount RiiserLarsen. In this case, the older $c a .3 .8$ Ga population is either xenocrystic, or the Gage Ridge orthogneiss is composite, containing magmatic protoliths of different ages that have been combined and obscured by the $2.5 \mathrm{Ga}$ tectonic event. It is also possible that the $c a .3 .3 \mathrm{Ga}$ group does not represent a stage of zircon growth, but consists of older zircon that has been affected by a combination of incomplete $\mathrm{Pb}$ loss and $\mathrm{Pb}$ remobilization, so that the data deviate significantly from the discordia chord. Unfortunately, there are no clear textural or chemical criteria that allow us to resolve these alternatives; the presence of an event at $3.3 \mathrm{Ga}$ remains a hypothesis to be tested by further investigations. Although the presence of zircon with concordant ages of $c a .4 .0$ Ga was not confirmed, this study does not rule out their presence. The $c a .3 .8$ Ga intercept age for zircon growth in the Gage Ridge orthogneiss matches previous age estimates and reinforces the interpretation that this is the age of the magmatic protolith.

\section{Chemical Features of Zircon Affected by UHT}

Radiation damaged zircon.-To test if there is a direct correlation between $\mathrm{Pb}$ mobilization and radiation damage, we utilized Raman spectroscopy to determine the degree of metamictization in the same zircon domains previously imaged by SIMS (Kusiak and others, 2013). On the Raman maps, differences in intensity, Raman shift and FWHM define domains with different degrees of metamictization (fig. 6). When the Raman maps are compared to $\mathrm{Pb}$ concentration maps of the same areas (Kusiak and others, 2013), it is evident that there is no correlation and that $\mathrm{Pb}$ is patchily distributed regardless of the degree of crystallinity.

Rare Earth Elements. - The REE distributions in zircon from all three samples are mostly similar, with steep MREE to LREE trends (fig. 5). A few analyses of zircon from the Mount Sones and Dallwitz Nunatak paragneisses have elevated LREE contents that probably reflect either micro-inclusions of LREE-rich minerals, such as monazite, or radiation-damaged zircon altered by LREE-bearing fluids (compare Cavosie and others, 2006). The steep MREE to HREE trends of all zircon analyses are consistent with an igneous origin. However, such patterns are also present in metamorphic zircon grown in the absence of garnet. Zircon analyses from the Mount Sones sample fall along a discordia line with an upper intercept age of $2.8 \mathrm{Ga}$, and this is interpreted as the time of zircon growth: consistently low Th/U values $(<0.12)$ support this interpretation. A similar $2.8 \mathrm{Ga}$ generation of zircon was identified as metamorphic in origin by 
Kelly and Harley (2005) in an orthogneiss from Dallwitz Nunatak. Like our sample from Mount Sones, their sample contained garnet that grew during UHT metamorphism, but the 2.8 Ga metamorphic zircon lacked the HREE depletion characteristic of zircon grown in equilibrium with garnet. Instead, Kelly and Harley (2005) suggested that $2.8 \mathrm{Ga}$ zircon grew during metamorphism under high-temperature, low-pressure conditions in the absence of garnet. A similar interpretation for the 2.8 Ga zircons from Mount Sones is likely. Metamorphic zircon grown at $2.5 \mathrm{Ga}$ in the Gage Ridge orthogneiss sample also has a steep MREE to HREE trend; however, this is consistent with growth during UHT metamorphism, as the composition likely precluded the growth of garnet and the rock may have undergone anatexis.

Oxygen.-Oxygen analyses were performed to test if there was any evidence of disturbance in zircon grains during metamorphism. The $\delta^{18} \mathrm{O}$ values vary between samples (fig. 4) and there is an increase in $\delta^{18} \mathrm{O}$ with age from the Gage Ridge orthogneiss (average $\delta^{18} \mathrm{O}=5.8 \%$ ) to the paragneisses: Dallwitz Nunatak sample (average $\delta^{18} \mathrm{O}=7.4 \% 0$ ) and Mount Sones sample (average $\delta^{18} \mathrm{O}=8.1 \% 0$ ). Zircons from paragneisses thus yield significantly higher values than zircons from the Gage Ridge orthogneiss. Whereas both ages and $\delta^{18} \mathrm{O}$ values are scattered in the Dallwitz Nunatak sample, suggesting a detrital origin for the zircon, the values from Mount Sones are quite uniform. Both the high values and the low scatter in $\delta^{18} \mathrm{O}$ in zircon from the Mount Sones sample are consistent with growth during 2.8 Ga metamorphism, as proposed above. Igneous zircons from Gage Ridge show a narrow range (4.7-6.8\%o) of values that are consistent with igneous zircon derived from a magma whose protolith formed by melting of the mantle (Valley, 2003; Cavosie and others, 2006), or of juvenile crust recently formed from mantle sources.

UHT metamorphism.- The presence of $\mathrm{Pb}$ micro-domains supports the earlier inference by Williams and others (1984) of $\mathrm{Pb}$ remobilization, but without $\mathrm{Pb}$ loss from the zircon grains. This is likely to have occurred in an environment deficient in fluids, since these would assist recrystallization and transport $\mathrm{Pb}$ out of the crystals. Consequently, we suggest that annealing under elevated temperatures and fluid-absent conditions is the most likely mechanism by which $\mathrm{Pb}$ is redistributed in the Napier Complex zircons. The gneisses of the Tula Mountains are exceptionally $\mathrm{H}_{2} \mathrm{O}$ poor, as a result of UHT metamorphism, and it is conceivable that this caused the unusual behavior of $\mathrm{Pb}$ in these zircons. However, thermal annealing of metamict zircon should begin at temperatures below UHT conditions, even in the case of dry annealing $\left(<800{ }^{\circ} \mathrm{C}\right)$, as indicated by experimental data (Váczi and others, 2009). If this is the case, annealing and $\mathrm{Pb}$ remobilization may have begun in prograde or pre-UHT stages of metamorphism, possibly in gneisses that were already lacking $\mathrm{H}_{2} \mathrm{O}$-bearing phases. Such may be the case for the Mount Sones paragneiss, especially if it had been previously metamorphosed to granulite-facies at $c a .2 .8 \mathrm{Ga}$.

\section{Reverse Discordance}

Reverse discordance is rarely observed in zircon analyses where $\mathrm{Pb}$ and $\mathrm{U}$ are extracted and homogenized by dissolution (McLaren and others, 1994). However, during ion microprobe analysis of micro-domains in single crystals, the problem of reverse discordance has been recognized for more than 25 years (Williams and others, 1984). It has been investigated in a number of studies that have led to a variety of explanations. Black and others (1991) observed that in individual samples, the most U-rich zircon is the most reversely discordant. Under temperatures low enough for $\alpha$-recoil damage to accumulate, $\mathrm{U}$ content correlates with the rate of radiation damage. Harrison and others (1987) suggested that lattice damage in U-rich zircon creates an anomalous matrix that allows the net loss of $\mathrm{U}$ relative to $\mathrm{Pb}$. Reverse discordance measured by ion microprobe may potentially result from the different sputtering characteristics of variably labile components that contain $\mathrm{Pb}$, due to either different 
degrees of crystallinity or different lattice structures (Wiedenbeck, 1995). Alternatively, the degree of radiation damage may influence the diffusivity of $\mathrm{Pb}$, leading to localized regions of $\mathrm{Pb}$ loss or gain. Williams and others (1984) suggested that reverse discordance is due to genuine local excesses of "unsupported" radiogenic $\mathrm{Pb}$, and is not an artifact of the measurement technique. Recently, Kusiak and others (2013) used ion probe imaging to demonstrate inhomogeneity of $\mathrm{Pb}$ on the micron scale in zircon from the Napier Complex, confirming the presence of unsupported radiogenic $\mathrm{Pb}$.

Lead is the stable daughter product of a series of $\alpha$-decay events from parent $\mathrm{U}$ and Th, and is located within amorphous regions or inter-atomic positions in the radiation-damaged crystal structure of zircon. Cherniak (2010) has shown that crystalline zircon is resistant to $\mathrm{Pb}$ diffusion below $900{ }^{\circ} \mathrm{C}$. Experimental studies by Geisler and others (2003) show that due to the incompatibility of $\mathrm{Pb}^{2+}$, radiogenic $\mathrm{Pb}$ is excluded from recrystallized or newly-grown zircon. Both natural examples (Mezger and Krogstad, 1997) and experimental studies (Geisler and others, 2003) confirm that $\mathrm{Pb}$ loss is greater in metamict zircon where $\alpha$-recoil damage to the crystal lattice has occurred to a point where damaged domains overlap, producing a kind of "permeability" (Geisler and others, 2003). However, metamictization itself is not the cause of $\mathrm{Pb}$ mobility, but merely the pre-condition. The mobilization of $\mathrm{Pb}$ still requires a driving force, occurring either through the permeation of fluids into metamict zircon, transporting $\mathrm{Pb}$ and inducing recrystallization, or through annealing at elevated temperatures, inducing repair of damaged structure that forces $\mathrm{Pb}$ elsewhere. When metamict zircons are reheated and recrystallized, only the parts of the crystal that were not metamict retain their lead; the most damaged parts reject $\mathrm{Pb}$ from the new crystal lattice (Mezger and Krogstad, 1997).

In the present study, the irregular distribution of $\mathrm{Pb}$ revealed by multi-collector ion-microprobe imaging (fig. 8) demonstrates mobilization of radiogenic $\mathrm{Pb}$ within the zircon grains. These micro-domains of $\mathrm{Pb}$ enrichment do not include common (non-radiogenic) $\mathrm{Pb}$ and have ${ }^{207} \mathrm{~Pb} /{ }^{206} \mathrm{~Pb}$ values that are higher than would be expected for radiogenic $\mathrm{Pb}$ accumulated since the formation of the zircon. This would not be the case if the variation in $\mathrm{Pb}$ intensity was merely due to differences in ion sputtering behavior during analysis. The high ${ }^{207} \mathrm{~Pb} /{ }^{206} \mathrm{~Pb}$ values also demonstrate that ancient $\mathrm{Pb}$ remobilization can result in spuriously old ages, in this case $>4 \mathrm{Ga}$. The ancient concentration of radiogenic $\mathrm{Pb}$ into micro-domains thus explains both the presence of reversely discordant ages, as well as the distribution of such ages in $\mathrm{U}-\mathrm{Pb}$ spot analyses along linear trends that intersect the concordia at the time of $\mathrm{Pb}$ remobilization, that is during 2.5 Ga metamorphism. However, grains selected for ion imaging in this study were deliberately chosen to be different in age, with their $\mathrm{U}$ contents varying between 165 and $3058 \mathrm{ppm}$. Ion imaging further emphasizes that areas of $\mathrm{Pb}$ enhancement are independent of $\mathrm{U}$ or Th content, as was the observation in our previous study (Kusiak and others, 2013). Our present results establish that $\mathrm{Pb}$ mobilization affected grains with a range of ages from $3.8 \mathrm{Ga}$ to $2.8 \mathrm{Ga}$, all of which underwent UHT metamorphism at $c a$. 2.5 Ga and possibly a low-P high-T event at ca. $2.8 \mathrm{Ga}$.

\section{CONCLUSIONS}

This study examined the response of zircons of different age to Archean highgrade metamorphism that resulted in $\mathrm{Pb}$ migration; we reach the following conclusions:

1. A U-Pb study of three gneissic samples from the Napier Complex, Antarctica, identified zircons that are reversely discordant. Zircons from the Mount Sones paragneiss support previous studies that indicated metamorphism at both 2.8 Ga and 2.5 Ga in the Napier Complex. Zircons from the Dallwitz Nunatak paragneiss yield ages that scatter between $3.5 \mathrm{Ga}$ and $2.5 \mathrm{Ga}$ and represent 
detrital grains that experienced variable $\mathrm{Pb}$ mobilization during metamorphism. Zircon grains from the Gage Ridge orthogneiss form multiple age groups, including a distinct $3.8 \mathrm{Ga}$ population and a spread of concordant ages between $c a$. $3.6 \mathrm{Ga}$ and $3.3 \mathrm{Ga}$. It is unclear if the older population is xenocrystic, and the protolith age $\leq 3.3 \mathrm{Ga}$, or if it is consistent with previous studies from the same locality, which favor an age of $3.8 \mathrm{Ga}$ for the protolith.

2. There is no evidence of oxygen and REE disturbance during UHT metamorphism, nor any relationship to $\mathrm{Pb}$ mobilization.

3. Pb-enriched patches yield ${ }^{207} \mathrm{~Pb} /{ }^{206} \mathrm{~Pb}$ ages $>4 \mathrm{Ga}$. These are not genuine ages, but the result of calculations from areas that contain both supported and unsupported radiogenic $\mathrm{Pb}$, the latter resulting from ancient mobilization. Isotope imaging of zircon grains by SIMS reveals that radiogenic $\mathrm{Pb}$ can be mobilized, resulting in local domains of Pb-loss and $\mathrm{Pb}$-gain which, over time, develop lower and higher apparent ${ }^{207} \mathrm{~Pb} /{ }^{206} \mathrm{~Pb}$ ages, respectively, with respect to their igneous crystallization age. Thus, the combination of unsupported and supported radiogenic $\mathrm{Pb}$ can yield spuriously old ${ }^{207} \mathrm{~Pb} /{ }^{206} \mathrm{~Pb}$ ages. This redistribution of $\mathrm{Pb}$ is unrelated to the $\mathrm{U}$ or $\mathrm{Th}$ concentration in the zircon, and to the degree of metamictization.

4. The best interpretation of the data is that reverse discordance in zircon from the Napier Complex is closely related with ancient $\mathrm{Pb}$ mobilization and this was most likely caused by polymetamorphism under anhydrous conditions; that is two high-temperature events-one low-P event at $c a .2 .8 \mathrm{Ga}$ and a UHT event at ca. $2.5 \mathrm{Ga}$.

\section{ACKNOWLEDGMENTS}

We thank Simon Harley and two anonymous reviewers for their thorough reviews. The work benefited from discussions with Chris Carson. Vickie Bennett, and Danny and Joan Rye are thanked for editorial handling of the manuscript. This research was supported by European Commission FP7 funding under the Capacity (Synthesys, TAF-952 225406-CP-Infra) and People (Marie Curie Fellowship, PIOF-GA-2010273412) Programmes to M. A. Kusiak. The NordSIMS ion microprobe facility is operated under a contract with the joint Nordic research councils, the Geological Survey of Finland and the Swedish Museum of Natural History. Technical support of Kerstin Lindén is greatly appreciated. This is TIGeR contribution no. 472 and NordSIMS contribution no. 349.

\section{REFERENCES}

Ahrens, L. H., 1955, Implications of the Rhodesian age pattern: Geochimica et Cosmochimica Acta, v. 8, n. 1-2, p. 1-15, http://dx.doi.org/10.1016/0016-7037(55)90013-2

Anders, E., and Grevesse, N., 1989, Abundances of the elements: Meteoritic and solar: Geochimica et Cosmochimica Acta, v. 53, n. 1, p. 197-214, http://dx.doi.org/10.1016/0016-7037(89)90286-X

Asami, M., Suzuki, K., and Grew, E. S., 2002, Chemical Th-U-total Pb dating by electron microprobe analysis of monazite, xenotime and zircon from the Archean Napier Complex, East Antarctica: evidence for ultra-high-temperature metamorphism at 2400 Ma: Precambrian Research, v. 114, n. 3-4, p. 249-275, http://dx.doi.org/10.1016/S0301-9268(01)00228-5

Belousova, E., Griffin, W., O'Reilly, S. Y., and Fischer, N., 2002, Igneous zircon: trace element composition as an indicator of source rock type: Contributions to Mineralogy and Petrology, v. 143, n. 5, p. 602-622, http://dx.doi.org/10.1007/s00410-002-0364-7

Belyatsky, B. V., Rodinov, N. V., Antonov, A. V., and Sergeev, S. A., 2011, The 3.98-3.63 Ga zircons as indicators of major processes operating in the ancient continental crust of the East Antarctic Shield (Enderby Land): Doklady Earth Sciences, v. 438, n. 2, p. 770-774, http://dx.doi.org/10.1134/ S1028334X11060031

Black, L. P., James, P. R., and Harley, S. L., 1983a, Geochronology and geological evolution of metamorphic rocks in the Field Island area, East Antarctica: Journal of Metamorphic Geology, v. 1, n. 4, p. 277-303, http://dx.doi.org/10.1111/j.1525-1314.1983.tb00276.x

1983b, The geochronology, structure and metamorphism of early Archaean rocks at Fyfe Hills, 
Enderby Land, Antarctica: Precambrian Research, v. 21, n. 3-4, p. 197-222, http://dx.doi.org/10.1016/ 0301-9268(83)90041-4

Black, L. P., Sheraton, J. W., and James, P. R., 1986a, Late Archaean granites of the Napier Complex, Enderby Land, Antarctica: a comparison of $\mathrm{Rb}-\mathrm{Sr}$, $\mathrm{Sm}-\mathrm{Nd}$ and U-Pb systematics in a complex terrain: Precambrian Research, v. 32, n. 4, p. 343-368, http://dx.doi.org/10.1016/0301-9268(86)90036-7

Black, L. P., Williams, I. S., and Compston, W., 1986b, Four zircon ages form one rock: the history of a 3930 Ma-old granulite form Mount Sones, Enderby Land, Antarctica: Contributions to Mineralogy and Petrology, v. 94, n. 4, p. 427-437, http://dx.doi.org/10.1007/BF00376336

Black, L. P., Kinny, P. D., and Sheraton, J. W., 1991, The difficulties of dating mafic dykes: an Antarctic example: Contributions to Mineralogy and Petrology, v. 109, n. 2, p. 183-194, http://dx.doi.org/ 10.1007 /BF00306478

Bowring, S. A., Williams, I. S., and Compston, W., 1989, 3.96 Ga gneisses from the Slave province, Northwest Territories, Canada: Geology, v. 17, n. 11, p. 971-975, http://dx.doi.org/10.1130/0091-7613(1989)017 $\langle 0971$ :GGFTSP $\rangle$ 2.3.CO;2

Carson, C. J., Ague, J. J., and Coath, C. D., 2002a, U-Pb geochronology from Tonagh Island, East Antarctica: implications for the timing of ultra-high temperature metamorphism of the Napier Complex: Precambrian Research, v. 116, n. 3-4, p. 237-263, http://dx.doi.org/10.1016/S0301-9268(02)00023-2

Carson, C. J., Ague, J. J., Grove, M., Coath, C. D., and Harrison, T. M., 2002b, U-Pb isotopic behavior of zircon during upper-amphibolite facies fluid infiltration in the Napier Complex, east Antarctica: Earth and Planetary Science Letters, v. 199, n. 3-4, p. 287310, http://dx.doi.org/10.1016/S0012-821X(02)00565-4

Cavosie, A. J., Valley, J. W., Wilde, S. A., and E.I.M.F., 2005, Magmatic $\delta^{18} \mathrm{O}$ in $4400-3900$ Ma detrital zircons: A record of the alteration and recycling of crust in the Early Archean: Earth and Planetary Science Letters, v. 235, n. 3-4, p. 663-681, http://dx.doi.org/10.1016/j.epsl.2005.04.028 2006, Correlated microanalysis of zircon: Trace element, $\delta^{18} \mathrm{O}$, and U-Th-Pb isotopic constraints on the igneous origin of complex $>3900$ Ma detrital grains: Geochimica et Cosmochimica Acta, v. 70, v. 22, p. 5601-5616, http://dx.doi.org/10.1016/j.gca.2006.08.011

Cherniak, D. J., 2010, Diffusion in accessory minerals: zircon, titanite, apatite, monazite and xenotime: Reviews in Mineralogy and Geochemistry, v. 72, n. 1, p. 827-869, http://dx.doi.org/10.2138/ rmg.2010.72.18

Cherniak, D. J., and Watson, E. B., 2003, Diffusion in zircon, in Hanchar, J. M., and Hoskin, P. W. O., editors, Zircon: Reviews in Mineralogy and Geochemistry, v. 53, p. 113-143, http://dx.doi.org/10.2113/ 0530113

Crowe, W. A., Osanai, Y., Toyoshima, T., Owada, M., Tsunogae, T., and Hokada, T., 2002, SHRIMP geochronology of a mylonite zone on Tonagh Island: characterization of the last high-grade tectonothermal event in the Napier Complex, East Antarctica: Polar Geoscience, v. 15, p. 17-36.

Dallwitz, W. B., 1968, Coexisting sapphirine and quartz in granulite from Enderby Land, Antarctica: Nature, v. 219, p. 476-477, http://dx.doi.org/10.1038/219476a0

Davis, D. W., Williams, I. S., and Krogh, T. E., 2003, Historical development of zircon geochronology, in Hanchar, J. M., and Hoskin, P. W. O., editors, Zircon: Reviews in Mineralogy and Geochemistry, v. 53, p. 145-181, http://dx.doi.org/10.2113/0530145

Geisler, T., Pidgeon, R. T., Kurtz, R., van Bronswijk, W., and Schleicher, H., 2003, Experimental hydrothermal alteration of partially metamict zircon: American Mineralogist, v. 88, n. 10, p. 1496-1513.

Grew, E. S., 1998, Boron and beryllium minerals in granulite-facies pegmatites and implications of beryllium pegmatites for the origin and evolution of the Archean Napier Complex of East Antarctica: Memoirs of National Institute of Polar Research Special Issue, v. 53, p. 74-92.

Grew, E. S., Suauki, K., and Asami, M., 2001, CHIME ages of xenotime, monazite and zircon from beryllium pegmatites in the Napier Coplex, Khmara Bay, Enderby Land, East Antarctica: Polar Geoscience, v. 14, p. 99-118.

Harley, S. L., 1985, Garnet-orthopyroxene bearing granulites from Enderby Land, Antarctica: metamorphic pressure-temperature-time evolution of the Archean Napier Complex: Journal of Petrology, v. 26, n. 4, p. 819-856, http://dx.doi.org/10.1093/petrology/26.4.819

1987, A pyroxene-bearing meta-ironstone and other pyroxene-granulites from Tonagh Island, Enderby Land, Antarctica: further evidence for very high temperature $\left(>980^{\circ} \mathrm{C}\right)$ Archaean regional metamorphism in the Napier Complex: Journal of Metamorphic Geology, v. 5, n. 3, p. 341-356, http://dx.doi.org/10.1111/j.1525-1314.1987.tb00389.x

Harley, S. L., and Black, L. P., 1997, A revised Archaean chronology for the Napier Complex, Enderby Land, from SHRIMP ion-microprobe studies: Antarctic Science, v. 9, n. 1, p. 74-91, http://dx.doi.org/10.1017/ S0954102097000102

Harley, S. L., and Hensen, B. J., 1990, Archaean and Proterozoic high-grade terranes of East Antarctica $\left(40-80^{\circ} \mathrm{E}\right)$ : a case study of diversity in granulite facies metamorphism, in Ashworth, J. R., and Brown, M., editors, High-temperature Metamorphism and Crustal Anatexis (The Mineralogical Society Series): London, Unwin Hyman, p. 320-370.

Harley, S. L., and Kelly, N. M., 2007, Ancient Antarctica: The Archaean of the East Antarctic Shield, in van Kranendonk, M. J., Smithies, R. H., and Bennet, V. C., editors, Earth's Oldest Rocks: Developments in Precambrian Geology, v. 15, p. 149-186, http://dx.doi.org/10.1016/S0166-2635(07) 15032-5

Harley, S. L., and Motoyoshi, Y., 2000, Al zoning in orthopyroxene in a sapphirine quartzite: evidence for $>1,120^{\circ} \mathrm{C}$ UHT metamorphism in the Napier Complex, Antarctica, and implications for the entropy of sapphirine: Contributions to Mineralogy and Petrology, v. 138, n. 4, p. 293-307, http://dx.doi.org/ $10.1007 / \mathrm{s} 004100050564$

Harrison, T. M., Aleinikoff, J. N., and Compston, W., 1987, Observations and controls on the occurrence of inherited zircon in Concord-type granitoids, New Hampshire: Geochimica et Cosmochimica Acta, v. 51, n. 9, p. 2549-2558, http://dx.doi.org/10.1016/0016-7037(87)90305-X 
Hensen, B. J., and Motoyoshi, Y., 1992, Osumilite-producing reactions in high-temperature granulites from the Napier Complex, East Antarctica: tectonic implications, in Yoshida, Y., Kaminuma, K., and Shiraishi, K., editors, Recent progress in Antarctic Earth Science: Tokyo, Terra Scientifica Publishing Company, p. 87-92.

Hokada, T., Misawa, K., Shiraishi, K., and Suzuki, S., 2003, Mid to Late Archaean (3.3-2.5 Ga) tonalitic crustal formation and high-grade metamorphism at Mt. Riiser-Larsen, Napier Complex, East Antarctica: Precambrian Research, v. 127, n. 1-3, p. 215-228, http://dx.doi.org/10.1016/S0301-9268(03)00188-8

Hokada, T., Misawa, K., Yokoyama, K., Shiraishi, K., and Yamaguchi, A., 2004, SHRIMP and electron microprobe chronology of UHT metamorphism in the Napier Complex, East Antarctica: implications for zircon growth at $>1,000^{\circ} \mathrm{C}$ : Contributions to Mineralogy and Petrology, v. 147, n. 1, p. 1-20, http://dx.doi.org/10.1007/s00410-003-0550-2

Hokada, T., Motoyoshi, Y., Suzuki, S., Ishikawa, M., and Ishizuka, H., 2008, Geodynamic evolution of Mt. Riiser-Larsen, Napier Complex, East Antarctica, with reference to the UHT mineral associations and their reaction relations, in Satishi-Kumar, M., Motoyoshi, Y., Osanai, Y., Hiroi, Y., and Shiraishi, K., editors, Geodynamic evolution of East Antarctica: A key to the East-West Gondwana Connection: Geological Society, London, Special Publications, v. 308, p. 253-282, http://dx.doi.org/10.1144/ SP308.13

Hollis, J. A., and Harley, S. L., 2002, New evidence for the peak temperatures and the near-peak pressure-temperature evolution of the Napier Complex, in Gamble, J. A., Skinner, D. N. B., and Henrys, S., editors, Antarctica at the close of a millennium: Wellington, The Royal Society of New Zealand, Proceedings of the $8^{\text {th }}$ International Symposium on Antarctic Earth Sciences, p. 19-30.

Horie, K., Hokada, T., Hiroi, Y., Motoyoshi, Y., and Shiraishi, K., 2012, Contrasting Archaean crustal records in western part of the Napier Complex, East Antarctica: New constraints from SHRIMP geochronology: Gondwana Research, v. 21, n. 4, p. 829-837, http://dx.doi.org/10.1016/j.gr.2011.08.013

Hoskin, P. W. O., and Schaltegger, U., 2003, The composition of zircon and igneous and metamorphic petrogenesis, in Hanchar, J. M., and Hoskin, P. W. O., editors, Zircon: Reviews in Mineralogy and Geochemistry, v. 53, p. 27-62, http://dx.doi.org/10.2113/0530027

Irmer, G., 1985, Zum Einfluss der Apparatefunktion auf die Bestimmung von Streuquerschnitten und Lebensdauern aus optischen Phononenspektren: Experimentelle Technik der Physik, v. 33, p. 501-506.

Ishizuka, H., 2008a, An overview of geological studies of JARE in the Napier Complex, Enderby Land, East Antarctica, in Satish-Kumar, M., Osanai, Y., Hiroi, Y., and Shiraishi, K., editors, Geodynamic Evolution of East Antarctica: A Key to the East-West Gondwana Connection: Geological Society, London, Special Publications, v. 308, p. 121-138, http://dx.doi.org/10.1144/SP308.5

2008b, Protoliths of the Napier Complex in Enderby Land, East Antarctica; an overview and implications for crustal formation of Archaean continents: Journal of Mineralogical and Petrological Sciences, v. 103, n. 4, p. 218-225, http://dx.doi.org/10.2465/jmps.080328

James, P. R., and Black, L. P., 1981, A review of the structural evolution and geochronology of the Archaean Napier Complex of Enderby Land, Australian Antarctic Territory, in Glover, J. A., and Groves, D. J., editors, Archaean geology: Geological Society of Australia Special Publication, v. 7, p. 71-83.

Kelly, N. M., and Harley, S. L., 2005, An integrated microtextural and chemical approach to zircon geochronology: refining the Archaean history of the Napier Complex, east Antarctica: Contributions to Mineralogy and Petrology, v. 149, n. 1, p. 57-84, http://dx.doi.org/10.1007/s00410-004-0635-6

Kelly, N. M., Clarke, G. L., and Fanning, C. M., 2005, Archaean crust in the Rayner Complex of east Antarctica: Oygaren Group of islands, Kemp Land: Transactions of the Royal Society of Edinburgh: Earth Sciences, v. 95, n. 3-4, p. 491-510, http://dx.doi.org/10.1017/S0263593300001176

Kusiak, M. A., Whitehouse, M. J., Wilde, S. A., Nemchin, A. A., and Clark, C., 2013, Mobilization of radiogenic $\mathrm{Pb}$ in zircon revealed by ion imaging: Implications for early Earth geochronology: Geology, v. 41, n. 3, p. 291-294, http://dx.doi.org/10.1130/G33920.1

McLaren, A. C., FitzGerald, J. D., and Williams, I. S., 1994, The microstructure of zircon and its influence on the age determination from $\mathrm{Pb} / \mathrm{U}$ isotopic ratios measured by ion microprobe: Geochimica et Cosmochimica Acta, v. 58, n. 2, p. 993-1005, http://dx.doi.org/10.1016/0016-7037(94)90521-5

Mezger, K., and Krogstad, E. J., 1997, Interpretation of discordant U-Pb ages: An evaluation: Journal of Metamorphic Geology, v. 15, n. 1, p. 127-140, http://dx.doi.org/10.1111/j.1525-1314.1997.00008.x

Nasdala, L., Irmer, G., and Wolf, D., 1995, The degree of metamictization in zircon; a Raman spectroscopic study: European Journal of Mineralogy, v. 7, p. 471-478.

Osanai, Y., Toyoshima, T., Owada, M., Tsunogae, T., Hokada, T., and Crowe, W. A., 1999, Geology of ultrahigh-temperature metamorphic rocks from Tonagh Island in the Napier Complex, East Antarctica: Polar Geoscience, v. 12, p. 1-28.

Pearce, N. J. G., Perkins, W. T., Westgate, J. A., Gorton, M. P., Jackson, S. E., Neal, C. R., and Chenery, S. P., 1997, A compilation of new and published major and trace element data for NIST SRM 610 and NIST SRM 612 glass reference materials: Geostandard Newsletter, v. 21, n. 1, p. 115-144, http://dx.doi.org/ 10.1111/j.1751-908X.1997.tb00538.x

Peck, W. H., Valley, J. W., and Graham, C. M., 2003, Slow oxygen diffusion rates in igneous zircon from metamorphic rocks: American Mineralogist, v. 88, n. 7, p. 1003-1014.

Sandiford, M., and Wilson, C. J. L., 1984, The structural evolution of the Fyfe Hills-Khmara Bay region, Enderby Land, East Antarctica: Australian Journal of Earth Sciences, v. 31, n. 4, p. 403-426, http:// dx.doi.org/10.1080/08120098408729301

Sheraton, J. W., Tingey, R. J., Black, L. P., Offe, L. A., and Ellis, D. J., 1987, Geology of Enderby Land and western Kemp Land, Antarctica: Bureau of Mineral Resources, Bulletin-Australia, v. 223, p. 1-51.

Shimizu, H., Tsunogae, T., and Santosh, M., 2012, Petrology and phase equilibrium modeling of sapphirine + quartz assemblage from the Napier Complex, East Antarctica: diagnostic evidence for 
Neoarchean ultra-high temperature metamorphism: Geoscience Frontiers, http://dx.doi.org/10.1016/ j.gsf.2012.09.001

Shimizu, N., and Hart, S. R., 1982, Isotope fractionation in secondary ion mass spectrometry: Journal of Applied Physics, v. 53, n. 3, p. 1303-1311, http://dx.doi.org/10.1063/1.330636

Shiraishi, K., Dunkley, D. J., Hokada, T., Fanning, C. M., Kagami, H., and Hamamoto, T., 2008, Geochronological constraints on the late Proterozoic to Cambrian crustal evolution of eastern Dronning Maud Land, East Antarctica: a synthesis of SHRIMP U-Pb age and Nd model age data, in Satish-Kumar, M., Motoyoshi, Y., Osanai, Y., Hiroi, Y., and Shiraishi, K., editors, Geodynamic evolution of East Antarctica: A key to the East-West Gondwana Connection: Geological Society, London, Special Publications, v. 308, p. 21-67, http://dx.doi.org/10.1144/SP308.2

Speer, J. A., 1980, Zircon, in Ribbe, P., editor, Orthosilicates ( $2^{\text {nd }}$ edition): Reviews in Mineralogy and Geochemistry, v. 5, p. 67-112.

Stacey, J. S., and Kramers, J. D., 1975, Approximation of terrestrial lead isotope evolution by a two-stage model: Earth and Planetary Science Letters, v. 26, n. 2, p. 207-221, http://dx.doi.org/10.1016/0012821X(75) $90088-6$

Suzuki, S., Arima, M., Williams, I. S., Shiraishi, K., and Kagami, H., 2006, Thermal history of the UHT metamorphism in the Napier Complex, East Antarctica: insights from zircon, monazite, and garnet ages: Journal of Geology, v. 114, n. 1, p. 65-84, http://dx.doi.org/10.1086/498100

Suzuki, S., Ishizuka, H., and Kagami, H., 2008, Early to middle Proterozoic dykes in the Mt. Riiser-Larsen area of the Napier Complex, East Antarctica; tectonic implications as deduced from geochemical studies, in Satish-Kumar, M., Motoyoshi, Y., Osanai, Y., Hiroi, Y., and Shiraishi, K., editors, Geodynamic evolution of East Antarctica: A key to the East-West Gondwana Connection: Geological Society, London, Special Publications, v. 308, p. 195-210, http://dx.doi.org/10.1144/SP.308.10

Toyoshima, T., Osanai, Y., and Nogi, Y., 2008, Macroscopic geological structures of the Napier and Rayner Complexes, East Antarctica, in Satish-Kumar, M., Motoyoshi, Y., Osanai, Y., Hiroi, Y., and Shiraishi, K., editors, Geodynamic evolution of East Antarctica: A key to the East-West Gondwana Connection: Geological Society, London, Special Publications, v. 308, p. 139-146, http://dx.doi.org/10.1144/ SP308.6

Váczi, T., Nasdala, L., Wirth, R., Mehofer, M., Libowitzky, E., and Häger, T., 2009, On the breakdown of zircon upon "dry" thermal annealing: Mineralogy and Petrology, v. 97, n. 1-2, p. 129-138, http:// dx.doi.org/10.1007/s00710-009-0087-9

Valley, J. W., 2003, Oxygen isotopes in zircon, in Hanchar, J. M., and Hoskin, P. O. W., editors, Zircon: Reviews in Mineralogy and Geochemistry, v. 53, p. 343-385, http://dx.doi.org/10.2113/0530343

White, L. T., and Ireland, T. R., 2012, High-uranium matrix effect in zircon and its implications for SHRIMP U-Pb age determinations: Chemical Geology, v. 306-307, p. 78-91, http://dx.doi.org/10.1016/ j.chemgeo.2012.02.025

Whitehouse, M. J., 2004, Multi-collector SIMS determination of trace lanthanides in zircon: Geostandards and Geoanalytical Research, v. 28, n. 2, p. 195-201, http://dx.doi.org/10.1111/j.1751-908X.2004. tb00736.x

Whitehouse, M. J., and Kamber, B. S., 2005, Assigning dates to thin gneissic veins in high-grade metamorphic terranes: a cautionary tale from Akilia, southwest Greenland: Journal of Petrology, v. 46, n. 2, p. 291318, http://dx.doi.org/10.1093/petrology/egh075

Whitehouse, M. J., and Nemchin, A. A., 2009, High precision, high accuracy measurement of oxygen isotopes in a large lunar zircon by SIMS: Chemical Geology, v. 261, n. 1-2, p. 32-42, http:/ /dx.doi.org/ 10.1016/j.chemgeo.2008.09.009

Whitehouse, M. J., and Platt, J. P., 2003, Dating high-grade metamorphism-constraints from rare-earth elements in zircon and garnet: Contributions to Mineralogy and Petrology, v. 145, n. 1, p. 61-74, http:/ /dx.doi.org/10.1007/s00410-002-0432-z

Whitehouse, M. J., Kamber, B. S., and Moorbath, S., 1999, Age significance of U-Th-Pb zircon data from early Archaean rocks of west Greenland-a reassessment based on combined ion-microprobe and imaging studies: Chemical Geology, v. 160, n. 3, p. 201-224, http://dx.doi.org/10.1016/S0009-2541(99)00066-2

Wiedenbeck, M., 1995, An example of reverse discordance during ion microprobe zircon dating: An artifact of enhanced ion yields from a radiogenic labile Pb: Chemical Geology, v. 125, n. 1-3, p. 197218, http://dx.doi.org/10.1016/0009-2541(95)00072-T

Wiedenbeck, M., Allé, P., Corfu, F., Griffin, W. L., Meier, M., Oberli, F., von Quadt, A., Roddick, J. C., and Spiegel, W., 1995, Three natural zircon standards for U-Th-Pb, Lu-Hf, trace element and REE analyses: Geostandards Newsletter, v. 19, n. 1, p. 1-23, http://dx.doi.org/10.1111/j.1751-908X.1995.tb00147.x

Williams, I. S., Compston, W., Black, L. P., Ireland, T. R., and Forster, J. J., 1984, Unsupported radiogenic Pb in zircon: a cause of anomalously high $\mathrm{Pb}-\mathrm{Pb}, \mathrm{U}-\mathrm{Pb}$ and $\mathrm{Th}-\mathrm{Pb}$ ages: Contributions to Mineralogy and Petrology, v. 88, n. 4, p. 322-327, http://dx.doi.org/10.1007/BF00376756

Zeck, H. P., and Whitehouse, M. J., 1999, Hercynian, Pan-African, Proterozoic and Archean ion-microprobe zircon ages for a Betic-Rif core complex, Alpine belt, W Mediterranean-consequences for its P-T-t path: Contributions to Mineralogy and Petrology, v. 134, n. 2-3, p. 134-149, http://dx.doi.org/10.1007/ s004100050474

Zhang, M., Salje, E. K. H., Farnan, I., Graeme-Barber, A., Daniel, P., Ewing, R. C., Clark, A. M., and Leroux, H., 2000, Metamictization in zircon: Raman spectroscopic study: Journal of Physics Condensed Matter, v. 12, n. 8, p. 1915-1925, http://dx.doi.org/10.1088/0953-8984/12/8/333 